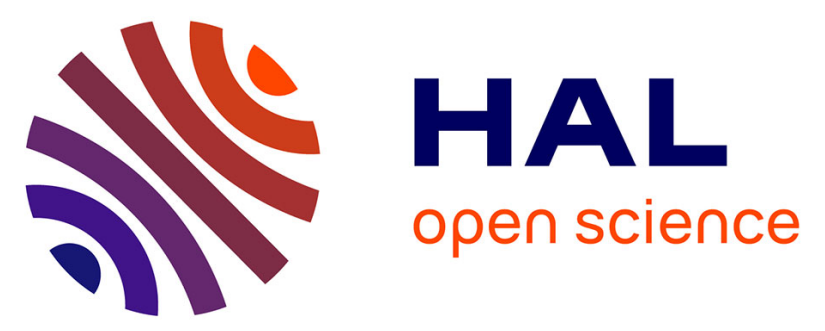

\title{
Structural and anisotropy of magnetic susceptibility records of granitoid sheets emplacement during growth of a continental gneiss dome (Central Sudetes, European Variscan Belt)
}

\author{
J. Lehmann, Karel Schulmann, J.-B. Edel, Josef Jezek, F. Hrouda, O. Lexa,
} F. Chopin

\section{To cite this version:}

J. Lehmann, Karel Schulmann, J.-B. Edel, Josef Jezek, F. Hrouda, et al.. Structural and anisotropy of magnetic susceptibility records of granitoid sheets emplacement during growth of a continental gneiss dome (Central Sudetes, European Variscan Belt). Tectonics, 2013, 32 (3), pp.797-820. 10.1002/tect.20028 . hal-00933183

\section{HAL Id: hal-00933183 https://hal.science/hal-00933183}

Submitted on 27 Feb 2022

HAL is a multi-disciplinary open access archive for the deposit and dissemination of scientific research documents, whether they are published or not. The documents may come from teaching and research institutions in France or abroad, or from public or private research centers.
L'archive ouverte pluridisciplinaire HAL, est destinée au dépôt et à la diffusion de documents scientifiques de niveau recherche, publiés ou non, émanant des établissements d'enseignement et de recherche français ou étrangers, des laboratoires publics ou privés. 


\title{
Structural and anisotropy of magnetic susceptibility records of granitoid sheets emplacement during growth of a continental gneiss dome (Central Sudetes, European Variscan Belt)
}

\author{
Jérémie Lehmann, ${ }^{1,2,3}$ Karel Schulmann, ${ }^{1,2}$ Jean-Bernard Edel, ${ }^{1}$ Josef Ježek, ${ }^{4}$ \\ František Hrouda, ${ }^{5}$ Ondrej Lexa, ${ }^{2,5}$ and Francis Chopin ${ }^{2,6}$ \\ Received 26 September 2012; revised 20 January 2013; accepted 3 February 2013; published 30 June 2013.
}

[1] Granitoid magmatic sheets emplaced syntectonically during growth of the Orlica-Śnieżnik mantled gneiss dome (Central Sudetes, European Variscan belt) were examined by means of structural geology, quartz, and anisotropy of magnetic susceptibility (AMS) fabric studies. Magmatic emplacement was localized along the eastern transpressive margin of the high metamorphic core and below the low-grade detached mantle rimming the southern margin of the dome. In the first area, the magmatic sheets were emplaced parallel to the dilated subhorizontal foliation of an anisotropic pre-orogenic block. The resulting melt-host rock multilayer localized the transpressive zone along which the bulk of magma was emplaced. The AMS study shows an across-strike fabric zonation underlying a strongly transpressive solid-state deformation in the hanging-wall, magmatic subhorizontal fabric in the foot-wall and a transitional fabric in the center of the intrusion. In contrast, along the southern dome margin, magmatic sheets intruded along steep foliations of weakly metamorphic mantle rocks, and are affected by recumbent folding and subhorizontal shearing. The bulk of the sheets present a shallow-dipping magmatic foliation and an along-strike magmatic lineation. The variations of the quartz and magnetic fabrics are attributed to superimposition of pure shear-dominated ductile thinning followed by simple shear-dominated detachment onto the original steep fabric. AMS modeling confirms the role of variation of orientation of pre-intrusive anisotropy during progressive deformation on the resulting fabric pattern and helps explaining observed variations in fabric orientations and symmetries. This study highlights contrasting mechanical behavior of syntectonically emplaced magmas in different parts of a growing crustal-scale mantled gneiss dome.

Citation: Lehmann, J., K. Schulmann, J.-B. Edel, J. Ježek, F. Hrouda, O. Lexa, and F. Chopin (2013), Structural and anisotropy of magnetic susceptibility records of granitoid sheets emplacement during growth of a continental gneiss dome (Central Sudetes, European Variscan Belt), Tectonics, 32, 797-820, doi:10.1002/tect.20028.

\footnotetext{
${ }^{1}$ Institut de Physique du Globe de Strasbourg, IPGS - UMR 7516, CNRS et Université de Strasbourg, Strasbourg, France.

${ }^{2}$ Center of Lithospheric Research, Czech Geological Survey, Prague, Czech Republic.

${ }^{3}$ Economic Geology Research Institute, School of Geosciences, University of the Witwatersrand, Johannesburg, South Africa.

${ }^{4}$ Institute of Applied Mathematics and Computer Sciences, Faculty of Science, Charles University, Prague, Czech Republic.

${ }^{5}$ Institute of Petrology and Structural Geology, Faculty of Science, Charles University, Prague, Czech Republic.

${ }^{6}$ Geosciences Azur, UMR 6526, CNRS et Université de Nice - Sophia Antipolis, Nice, France.

Corresponding author: J. Lehmann, Economic Geology Research Institute, School of Geosciences, University of the Witwatersrand, P O Wits, Johannesburg, 2050, South Africa. (jerelehmann@gmail.com)

(C)2013. American Geophysical Union. All Rights Reserved. 0278-7407/13/10.1002/tect.20028
}

\section{Introduction}

[2] Emplacement of large magmatic sheets in orogens is directly related to the problem of the role of melt-induced deformation in deep-crustal shear zones [Hollister and Crawford, 1986; Davidson et al., 1992]. It has been suggested that the melt production is responsible for melt pressure increase leading to embrittlement of the crust and development of melt-filled shear zones [Davidson et al., 1994]. The relationship between shear zones developed in various tectonic settings and melt transfer through the crust in the form of magmatic sheets has therefore been matter of discussion for several decades [Weinberg and Searle, 1998]. For instance, magmatic sheets emplaced in extensional settings parallel to high angle normal shear zones were reported from many areas [e.g., Hutton, 1988]. Similarly, narrow and elongated magmatic bodies are also known from areas of oblique divergence 
where magma was emplaced parallel to steep and transcurrent fault zones [e.g., Kratinová et al., 2007]. In compressional settings, it is widely assumed that magma cannot rise so easily because of the horizontal maximum principal stress and vertical least principal stress [e.g., Watanabe and Takahashi, 1994]. In such settings, the hydraulic fractures exploited by magma should be horizontal [Sibson, 2003]. However, a number of modern structural studies show that magmatic sills emplaced within crustal-scale thrust zones form large tabular bodies elongated parallel to the orogen and oriented at high angle to the maximum compression [Ingram and Hutton, 1994; Reichardt and Weinberg, 2012]. Therefore, the mechanism of emplacement of magma sheets at high angle to the horizontal shortening was discussed by several authors [e.g., Vernon and Paterson, 2001; Weinberg and Mark, 2008]. Galland et al. [2007] explored the mechanisms of granitoid sheets emplacement along thrust zones and proposed that the horizontal shortening and injection of magma are coeval but independent processes.

[3] A common structural geology problem is to what extent the internal fabric of magmatic sheets reflects the emplacement mechanism and the ambient tectonic regime [Paterson et al., 1998]. The internal fabric of magma is governed by the flow of melt and by the rotation of minerals in a displacement field generated by pressure gradient and by the geometry of the walls [e.g., Ježek et al., 1994; Ježek et al., 1996; Schulmann and Ježek, 2012]. However, the mineral fabric in granitoids is often poorly visible and then difficult to assess from mesoscopic observations. Because of this difficulty, the magmatic mineral fabrics are commonly quantified using the anisotropy of magnetic susceptibility (AMS), a method allowing rapid determination of orientation of fabric axes, intensity of deformation, and shape of fabric ellipsoid [Borradaile and Henry, 1997; Bouchez, 1997; Borradaile and Jackson, 2004]. Provided the magnetic mineralogy is well established, this technique yields rapid and highly precise fabric data that can be quantified [Bouchez, 2000], modeled [Benn, 1994; Ježek and Hrouda, 2002] and further interpreted in terms of complex flow histories [Benn, 2009; Schulmann and Ježek, 2012].

[4] In this paper, we present structural, quartz fabric, and AMS data of granitoid sheets emplaced along two structurally contrasting margins of the rising core of a crustal-scale mantled gneiss dome in the Central Sudetes (the Orlica-Śnieżnik Dome-OSD, Figure 1). The variations of AMS fabric are used to characterize emplacement of magmatic sheets, either parallel to a compressive wall of extruded gneiss dome [Parry et al., 1997], or along a ductile thinning/detachment zone unroofing the apical mantle part of the gneiss dome. The study of fabric zonation together with a detailed analysis of deformation microstructures and quartz fabrics allows us to identify late deformation increments related to variations in the bulk strain axes orientation. Then, an attempt is made to provide a mechanistic explanation of instantaneous strain regimes governing mechanisms of magmatic sheet emplacement during growth of a crustal-scale gneiss dome. Such models of emplacement are subsequently simulated by means of AMS modeling.

\section{Geological Setting}

[5] From the NW to SE, the Sudetes are defined by an east-dipping Devono-Carboniferous suture (Karkonosze
Complex), a Carboniferous orogenic root (OSD, Lugian Domain), and a Neoproterozoic microcontinent (Brunia, Moravo-Silesian Zone) [see Chopin et al., 2012a and references therein] (Figure 1). The orogenic domain consists of an exhumed orogenic lower crust represented by migmatitic gneisses forming the core of the OSD. It is mantled by lowto medium-grade schists and metabasites consisting of the Nové Město Unit in the west, the Zábřeh Unit in the south, and by a pre-orogenic mafic lower crustal fragment, the Staré Město Unit in the east [Chopin et al., 2012a].

[6] The OSD is composed of Barrovian-type middle Cambrian to early Ordovician metavolcano-sedimentary units [Skrzypek et al., 2011a; Mazur et al., 2012] and medium- to high-grade Cambro-Ordovician orthogneisses [e.g., van Breemen et al., 1982; Lange et al., 2005; Chopin et al., 2012b] which contain boudins of (U)HP rocks [Štipská et al., 2004; Štípská et al., 2012].

[7] The adjacent eastern Staré Město Unit is represented by a narrow band of NNE-SSW trending lithologies generally dipping to the W-WNW. The boundary with the core of the dome is marked by strongly deformed metapelites and late Cambrian sheared metagabbros [Kröner et al., 2000] along which, one of the two studied Carboniferous granitoid sheets were emplaced. The late Cambrian banded amphibolite complex [Kröner et al., 2000], located east of the granitoid sheets, consists of a layered sequence of alternating layered amphibolites, granulite facies gneisses, anatectic metasedimentary rocks and minor serpentinites.

[8] The southern part of the OSD is flanked by the lowgrade Zábřeh Unit which contains WNW-ESE trending belts of metavolcanic and metasedimentary rocks [Verner et al., 2009]. The base of the sequence is formed by amphibolites, paragneisses, and calc-silicate layers which grade to migmatitic paragneisses intruded by the WNW-ESE trending granitoid sheets, the other focus of this study, and terminates with metapelites and phyllites with acid metavolcanic rocks at the top. This unit shows a Barrovian metamorphism that can be traced downwards away from the dome, ranging from sillimanite paragneisses and staurolite schists in the north to greenschist phyllites in the south [Buriánek et al., 2003].

\section{Geology of the OSD Granitoids}

[9] The studied granitoid sheets of the OSD comprise: (1) $40 \mathrm{~km}$ long, up to $2 \mathrm{~km}$ wide, NNE-SSW trending sheeted bodies intruded in the Staré Město Unit, parallel to the eastern boundary of the OSD (here called the Staré Město Sheets, SMS), and (2) $30 \mathrm{~km}$ long and WNW-ESE trending magmatic sheets intruded in the Zábřeh Unit, parallel to the southern boundary of the OSD (here called the Zábřeh Unit Sheets, ZUS) (Figure 1).

[10] In the northernmost part of the Staré Město Unit, the SMS form a 1 to $2 \mathrm{~km}$ wide elongated and continuous granitoid intrusion in contact with mylonitic gabbros in the west, and late Cambrian amphibolite complex in the east. The boundaries between the intrusion and host rocks are always sharp. In the central part of the belt, the SMS become progressively thinner and form a sheeted array intruding the entire amphibolite complex. In the southern part of the belt, the SMS form a swarm of subparallel and discontinuous 


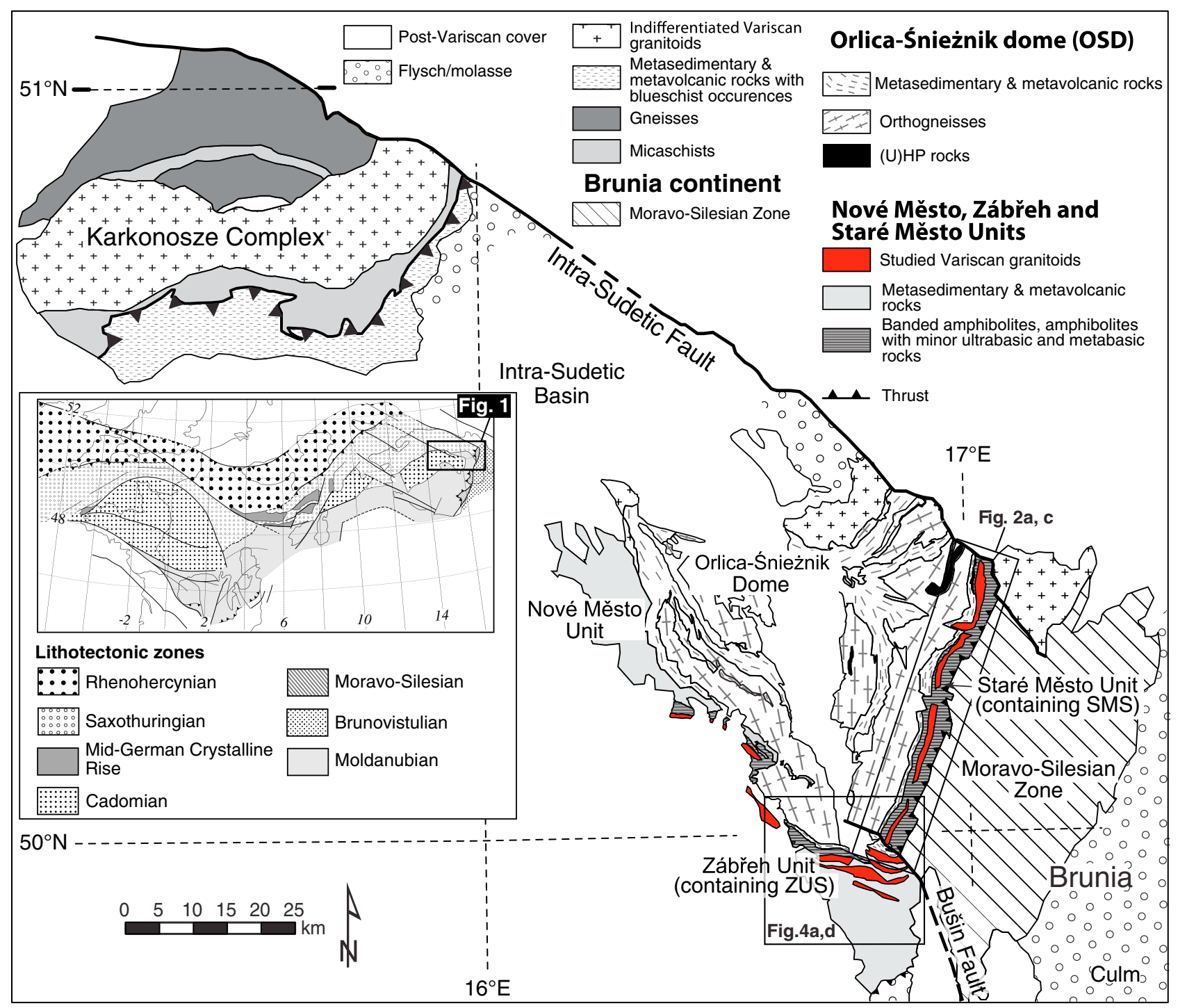

Figure 1. Simplified geological map of the Sudetes, modified after Aleksandrowski et al. [1997] and Franke and Zelazniewicz [2000]. Inset depicts the location of the study area within the Variscan Belt of Europe, modified after Edel et al. [2003] and Skrzypek et al. [2011b].

sheets $1 \mathrm{~m}$ to $100 \mathrm{~m}$ thick, alternating with leucocratic veins, migmatitic metasedimentary rocks, and amphibolites. The ZUS form elongated bodies up to $2 \mathrm{~km}$ wide emplaced within a $\sim 4 \mathrm{~km}$ wide belt of migmatitic paragneisses and migmatitic amphibolites.

[11] The intrusions can be divided into four rock groups according to their mineralogy. (1) The first group is represented by diorite enclaves which are confined to thick granodiorite sheets. These enclaves are composed of hornblende $(60-65 \%)$, plagioclase $(20-30 \%)$, very minor biotite $(0-5 \%)$, and relic clinopyroxene $(10 \%)$. (2) Coarse-grained $(>2 \mathrm{~mm})$ hornblende-biotite granodiorite is the main magmatic component through the whole area. It is composed of plagioclase $(30-40 \%)$, quartz $(20-25 \%)$, K-feldspar (5-15\%), biotite (5-20\%), hornblende (10-20\%), and rare relics of pyroxene. (3) Less abundant are monzogranites rich in plagioclase $(40-50 \%)$, K-feldspar $(10-20 \%)$, quartz $(20-35 \%)$, and rather poor in biotite $(5-15 \%)$ and hornblende $(0-5 \%)$. (4) The last group comprises local plagioclase ortho- to meso-cumulates with $70-80 \%$ plagioclase, minor biotite, and quartz. These rocks occur within the main magmatic bodies either as veins or as gneissified bodies. Typical accessory phases are titanite, magnetite, apatite, zircon, monazite, as well as secondary epidote, carbonate, chlorite, and muscovite. Monzogranites and plagioclase cumulates are dominantly developed in the central and southern parts of the SMS. According to Buriánek et al. [2003], the positive LILE anomalies of granodiorites are typical for calcalkaline magmatism, while REE spectra of the monzogranites suggest a syn-collisional context.

[12] The conditions of magma crystallization were estimated at $6.5-7 \mathrm{kbar}$ and $670-725^{\circ} \mathrm{C}$ for the SMS using $\mathrm{Hbl}-\mathrm{Pl}$ thermometry and hornblende $\mathrm{Al}$ contents [Parry et al., 1997], and at $2.9-4.3 \mathrm{kbar}$ and $705-770^{\circ} \mathrm{C}$ for the ZUS using identical methods as well as zircon saturation temperatures [Buriánek et al., 2003]. Higher pressures and similar temperatures for peak conditions were estimated for contact metamorphism related to granitoid magma emplacement: $8-10 \mathrm{kbar}$ 
and $710-750^{\circ} \mathrm{C}$ for the SMS using $\mathrm{Hbl}-\mathrm{Pl}$ thermobarometry [Štípská et al., 2001; Baratoux et al., 2005], and 4-6 kbar and $700-780^{\circ} \mathrm{C}$ for the ZUS estimated from a rock-bearing $\mathrm{LP}-\mathrm{HT}$ mineral assemblage $\mathrm{Grt}+\mathrm{Bt}+\mathrm{Sil}+\mathrm{Crd} \pm \mathrm{Ms} \pm \mathrm{Kfs}$ [Buriánek et al., 2003].

[13] The existing geochronological data point to almost coeval emplacement and rapid cooling of the SMS and ZUS. This is attested by: (1) ${ }^{207} \mathrm{~Pb} /{ }^{206} \mathrm{~Pb}$ zircon evaporation ages of $339.4 \pm 1.1 \mathrm{Ma}$ and $344.5 \pm 0.4 \mathrm{Ma}$ for the main body of granodiorite and a monzogranite dyke (SMS), respectively [Śtípská et al., 2004]; (2) a zircon age from a ZUS foliated granodiorite with a mean ${ }^{207} \mathrm{~Pb} /{ }^{206} \mathrm{~Pb}$ age of $338.1 \pm 1.3 \mathrm{Ma}$ [Kröner, unpublished data]; (3) hornblende ${ }^{40} \mathrm{Ar}{ }^{39} \mathrm{Ar}$ plateau ages of $344.4 \pm 4.4 \mathrm{Ma}$ and $345 \pm 6.8 \mathrm{Ma}$ for the cooling of granodiorites from the northern and central SMS, respectively [Chopin et al., 2012a], and a biotite ${ }^{40} \mathrm{Ar} /{ }^{39} \mathrm{Ar}$ plateau age at $338.2 \pm 0.5 \mathrm{Ma}$ from an adjacent gneiss [Schneider et al., 2006]; (4) an ${ }^{40} \mathrm{Ar} /{ }^{39} \mathrm{Ar}$ age of $336 \pm 3.2 \mathrm{Ma}$ for a hornblende in amphibolites from the foot-wall of the ZUS [Maluski et al., 1995]; and new ${ }^{40} \mathrm{Ar} /{ }^{39} \mathrm{Ar}$ ages of $346 \pm 9.7 \mathrm{Ma}$ and $342 \pm 4.3 \mathrm{Ma}$ for hornblende from amphibolites of the same area, and of $339.5 \pm 5.2 \mathrm{Ma}$ for a white mica from phyllonites sampled at the boundary between the Zábreh Unit and the OSD [Chopin et al., 2012a].

\section{Structural Evolution of the Host Rocks and Intrusions}

[14] The structural record of the host rocks and internal fabric patterns of the magmatic intrusions as well as deformation kinematics were studied separately for the SMS and ZUS intrusive systems.

\subsection{Staré Město Unit}

[15] The metamorphic rocks of the Staré Město Unit exhibit two superposed deformation events $D_{1 \mathrm{~s}}$ and $D_{2 \mathrm{~s}}$ (subscript $\mathrm{s}$ for SMS). The northern part of the Staré Město Unit is characterized by a gently north-dipping compositional banding $\mathrm{S}_{1 \mathrm{~s}}$ represented by the layered amphibolites and the gneissosity of granulitic tonalite gneisses (Figures $2 a$ and $2 b$ ) that developed during a late Cambrian extension [Štípská et al., 2001; Lexa et al., 2005]. This fabric is discordant to the main NNE-SSW trend of the Staré Město Unit and SMS granitoid sheets [Parry et al., 1997]. These granitoids show parallel magmatic $\mathrm{S}_{\mathrm{m}}$ and solid-state fabric $\mathrm{S}_{2 \mathrm{~s}}$ of early Carboniferous age and which are moderately dipping to the WNW (Figure $2 \mathrm{a}$ ). $\mathrm{S}_{2 \mathrm{~s}}$ is marked by dynamic recrystallization of plagioclase, amphibole, biotite, and quartz at amphibolite and greenschist facies. Locally, a strong, gently plunging NNE-SSW to N-S mineral and stretching lineation $\mathrm{L}_{2 s}$ is developed and is collinear with a magmatic lineation $\mathrm{L}_{\mathrm{m}}$ defined by alignment of amphiboles (Figure 2c). The sheared metagabbros from the hanging-wall were metamorphosed at LP granulite to amphibolite facies conditions during this episode [Baratoux et al., 2005]. $\mathrm{S}_{2 \mathrm{~s}}$ and $\mathrm{L}_{2 \mathrm{~s}}$ in these metagabbros are concordant with those of the underlying granodiorite as well as to those of the overlying schists and gneisses of the OSD (Figure 2b). Numerous kinematic indicators, like asymmetrical plagioclase and amphibole augen, and shear bands document dextral shearing [Cymerman, 1997, Parry et al., 1997; Baratoux et al., 2005].
[16] The southern termination of the northern part of the Staré Město Unit shows a change in trend from NNE to E-W (Figure 2a: Bielice valley). Here, several magmatic intrusions were emplaced parallel to greenschist facies gently north-dipping mylonitic late deformation zones $\mathrm{S}_{3 \mathrm{~s}}$, themselves cross-cutting steeply north-dipping $\mathrm{S}_{2 \mathrm{~s}}$ banding of layered amphibolites (Figures $2 \mathrm{a}$ and $3 \mathrm{a}$ ). The granitoid sheets carry a weak magmatic foliation to strong solid-state greenschist mylonitic fabric $\mathrm{S}_{3 \mathrm{~s}}$ defined by biotite elongated aggregates, recrystallized feldspars, and quartz arranged in ribbons (Figure $3 \mathrm{~b}$ ). $\mathrm{S}_{3 \mathrm{~s}}$ is associated with a strong NNEplunging mineral and stretching lineation $\mathrm{L}_{3 \mathrm{~s}}$ (Figure $2 \mathrm{c}$ ).

[17] Further south, the Staré Město Unit is dominated by metasedimentary rocks and the $\mathrm{S}_{1 \mathrm{~s}}$ foliation is transposed, as shown by folded amphibolites (Figure 2d), towards a new $\mathrm{S}_{2 \mathrm{~s}}$ fabric, axial plane of $\mathrm{F}_{2 \mathrm{~s}}$ folds, moderately to steeply dipping to the west. The magmatic sheets, several decimeters to meter thick, are locally undistinguishable from the granitic veins observed in the migmatites, which can be either of Cambrian or Carboniferous age [Parry et al., 1997; Kröner et al., 2000; Stípská et al., 2001]. In places these magmatic sheets are parallel to the former, locally preserved subhorizontal $\mathrm{S}_{1 \mathrm{~s}}$. More commonly, the magmatic bodies are parallel to the axial planes of $F_{2 s}$ folds, to the fold axes $B_{2 s}$ (Figure 3c), to the $\mathrm{S}_{2 \mathrm{~s}}$ compositional layering (Figure $3 \mathrm{~d}$ ) or are accumulated in necks of $\mathrm{D}_{2 \mathrm{~s}}$-related boudins (Figure $3 \mathrm{~d}$ ), and locally present a strong magmatic lineation $\mathrm{L}_{\mathrm{m}}$ (Figure $2 \mathrm{c}$ ). In some places, both horizontal and west-dipping magmatic sheets are observed together. The structures of the SMS are broadly concordant with the deformation fabrics observed in adjacent orthogneisses and micaschists of the OSD core (Figures 2b and 2d).

\subsection{Zábř̀h Unit}

[18] The structures recorded in the metamorphic rocks of the Zábreh Unit result from two deformation events $D_{1 z}$ and $\mathrm{D}_{2 \mathrm{z}}$ (subscript $\mathrm{z}$ for ZUS). The $\mathrm{D}_{1 \mathrm{z}}$ planar structures are steep and strike WNW-ESE in the whole belt, except in the easternmost area where the steep $S_{1 z}$ fabric locally strikes NNE-SSW (Figures $4 \mathrm{a}, 4 \mathrm{~b}$, and $4 \mathrm{c}$ ). $\mathrm{S}_{1 \mathrm{z}}$ is characterized by a compositional banding in the amphibolites and by a continuous schistosity in the metasedimentary rocks and phyllites further south. $\mathrm{D}_{1 \mathrm{z}}$ might be either Proterozoic or Late Devonian [Aleksandrowski et al., 1999; Mazur et al., 2006]. $D_{2 z}$ deformation is represented by a moderately SSW-dipping cleavage (Figures $4 \mathrm{a}, 4 \mathrm{~b}$, and 4c) interpreted as early Carboniferous in age [Chopin et al., 2012a]. In the north and foot-wall of the ZUS magmatic sheets, $\mathrm{D}_{2 \mathrm{z}}$ corresponds to an amphibolite facies mylonitic foliation in the orthogneisses, and to a compositional mylonitic layering with intrafolial boudinage in the amphibolites (Figure 5a). Here, $\mathrm{D}_{1 \mathrm{z}}$ is completely transposed, and only scarce rootless $\mathrm{F}_{2 \mathrm{z}}$ folds attest for relics of its former presence. $\mathrm{S}_{2 \mathrm{z}}$ is commonly associated with the development of a down-dip mineral stretching lineation $\mathrm{L}_{2 z d}$ (subscript $d$ for down-dip) defined by alignment of amphiboles and biotites in the amphibolites and by the stretching of quartzo-feldspathic rods and parallel alignment of biotites in orthogneisses. Farther south, in structurally higher position occupied by calc-silicates and paragneisses, $\mathrm{D}_{2 \mathrm{z}}$ is associated with north-verging Z-shaped asymmetrical tight to isoclinal gently south-inclined to recumbent folds (Figure 5b). The 


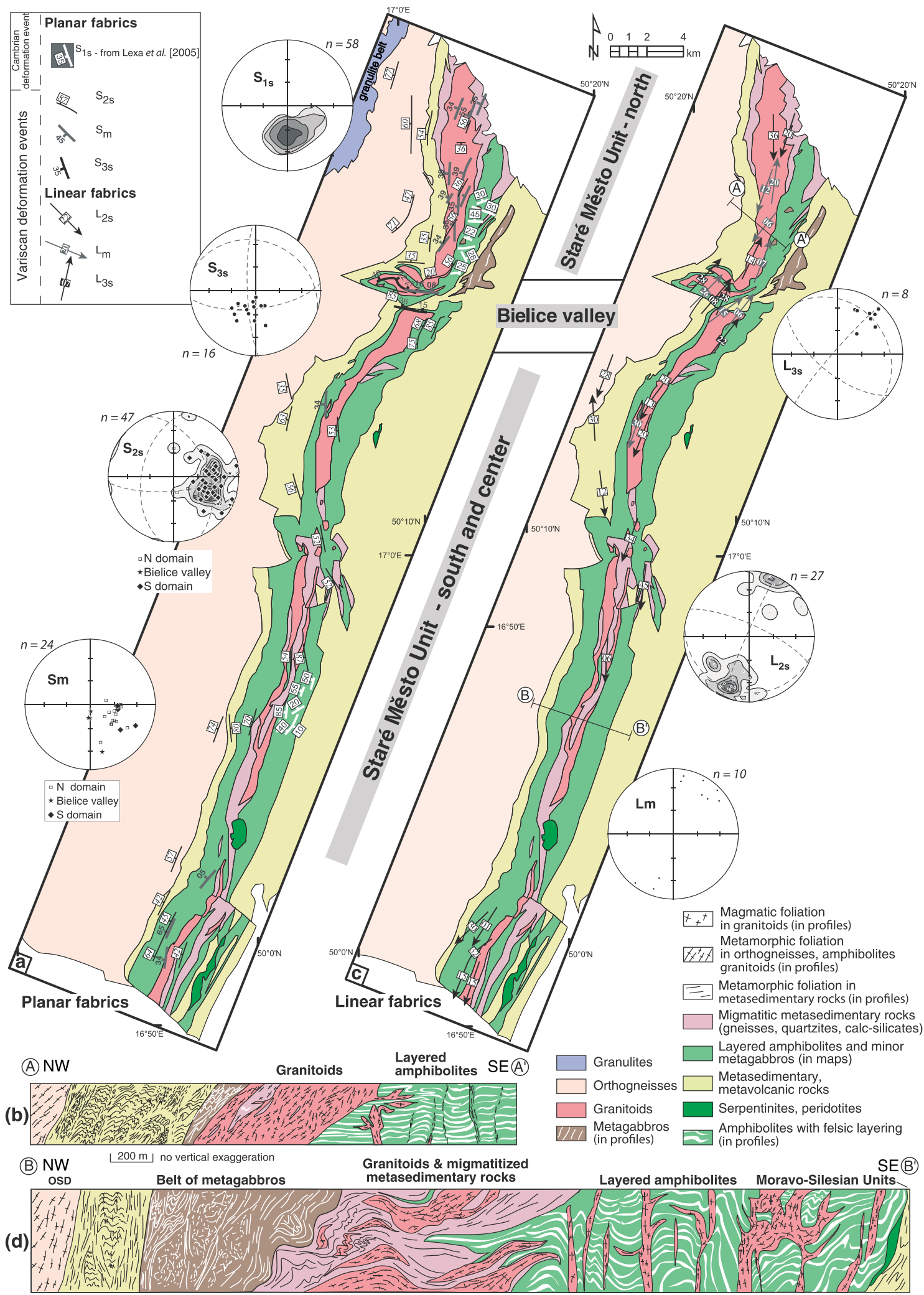

Figure 2. Structural maps, orientation diagrams of fabrics, and idealized structural profiles of the Staré Město Unit. Maps of (a) planar and (c) linear fabrics. Structural trends show extrapolations of the main orientations of fabrics measured in the field. Orientation diagrams represent average poles of foliations and orientation of lineations in equal-area lower-hemisphere projection. (b) and (d) Interpretative structural profiles modified from Lexa et al. [2005] displaying major structures relationships, lithologies of individual units, and major tectonic boundaries. (b) Profiles A-A' across the northern part, and (d) B-B' through the central part (location in Figure 2c). 

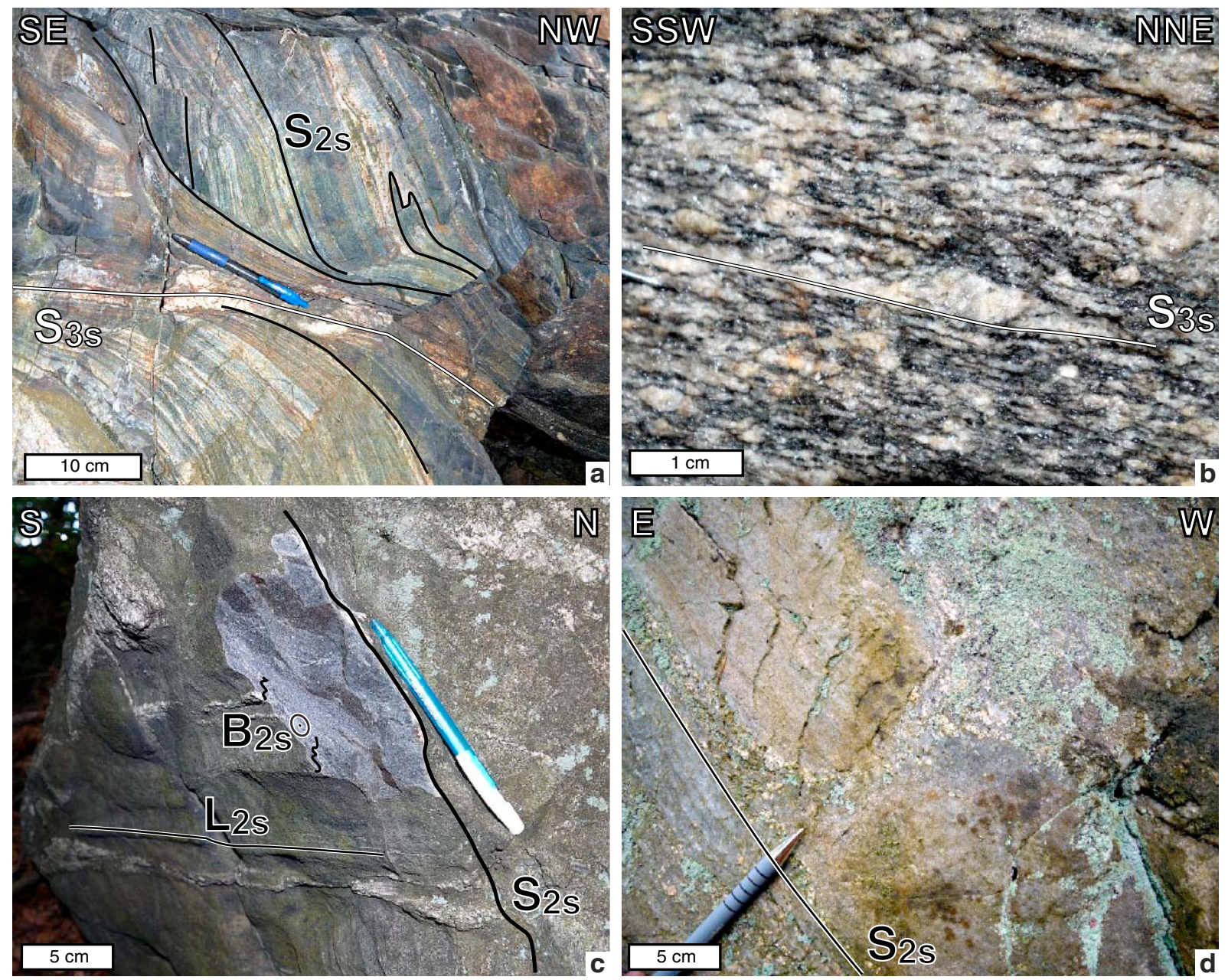

Figure 3. Field photographs showing the main structural features of the Staré Město Unit (vertical outcrops). (a) and (b) Bielice valley (located in Figure 2a): (a) $S_{2 s}$ compositional layering in amphibolites (steep and N-dipping), bent into the greenschist facies gently NNE-dipping cleavage $S_{3 s}$. (b) $S_{3 s}$ foliation developed in greenschist facies conditions in a 100 m-thick granodioritic layer. (c) and (d) Central and southern parts of the SMS: (c) $\mathrm{S}_{2 \mathrm{~s}}$ fabric in migmatitic amphibolite gneisses viewed parallel to the $\mathrm{B}_{2 \mathrm{~s}}$ axis of a $\mathrm{F}_{2 \mathrm{~s}}$ fold; coarse-grained quartzo-feldspathic melt collection occurs parallel to the $\mathrm{L}_{2 \mathrm{~s}}$ lineation and $\mathrm{B}_{2 \mathrm{~s}}$ axis, producing prolate-shaped magmatic bodies. (d) Quartzitic paragneisses with granitic material injected along $\mathrm{S}_{2 \mathrm{~s}}$ planes and in a $\mathrm{D}_{2 \mathrm{~s}}$-related boudin's neck.

$\mathrm{S}_{1-2 \mathrm{z}}$ and $\mathrm{S}_{2 \mathrm{z}}$ surfaces within calc-silicates present two sets of mineral lineations: a down-dip $\mathrm{L}_{2 \mathrm{zd}}$ stretching lineation, and a shallow-dipping NW-SE trending intersection and mineral lineation $L_{2 z}$, parallel to the hinges of the $F_{2 z}$ folds and to the intersection between the $S_{1 z}$ and $S_{2 z}$ planes (Figures $4 \mathrm{~d}$ and $5 \mathrm{~b}$ ). Farther south, in schists of the higher structural level, $\mathrm{D}_{2 z}$ forms rather symmetrical open folds with an axial planar cleavage $S_{2 z}$ defined by the alignment of biotite, muscovite, and syn- $S_{2 z}$ andalusite (oriented parallel to $\mathrm{S}_{2 \mathrm{z}}$ ). $\mathrm{F}_{2 \mathrm{z}}$ folding is associated with a strong WNW-ESE trending subhorizontal mineral and intersection lineation $\mathrm{L}_{2 z}$ (Figures $4 \mathrm{~d}$ and $5 \mathrm{c}$ ).

[19] The Zábřreh Unit comprises 16 magmatic sheets broadly oriented parallel to the trend of $S_{1 z}$ (Figure 4a) and reaching a thickness of $1.5 \mathrm{~km}$. To the west, these bodies are circular to slightly elliptical in map view, whereas in the east they are strongly elongated.
[20] There are metamorphic aureoles around the intrusions; their structure is characterized by intimate relationships between the ZUS and the host rock deformations. The granitic leucosomes are developed along $\mathrm{S}_{1 \mathrm{z}}$ and $\mathrm{S}_{2 \mathrm{z}}$ while the granitoid magma is mainly collected along the $S_{2 z}$ planes and the $F_{2 z}$ fold hinges (Figures $4 b, 4 c$, and $5 d$ ). The magmatic fabric of the intrusions is characterized by the preferred orientation of meter-scale microdioritic enclaves in granodiorites, xenoliths of gneissic hornfels, numerous schlierens, and orientation of primary magmatic minerals such as hornblende, feldspar porphyroclasts, and biotites. These magmatic planar $\left(\mathrm{S}_{\mathrm{m}}\right)$ and linear $\left(\mathrm{L}_{\mathrm{m}}\right)$ elements commonly agree with the orientations of $\mathrm{S}_{2 z}$ and $\mathrm{L}_{2 z}$ of the host rocks $\left(\mathrm{S}_{\mathrm{m}}\right.$ and $\mathrm{L}_{\mathrm{m}}$, Figures $4 \mathrm{e}$ and $4 \mathrm{~d}$, respectively). In the western part of the Zábřeh Unit, the ZUS rocks carry a strong, pervasive, and ubiquitous solid-state $S_{2 z}$ foliation, defined by fractured amphiboles and feldspars, ribbons of quartz and 


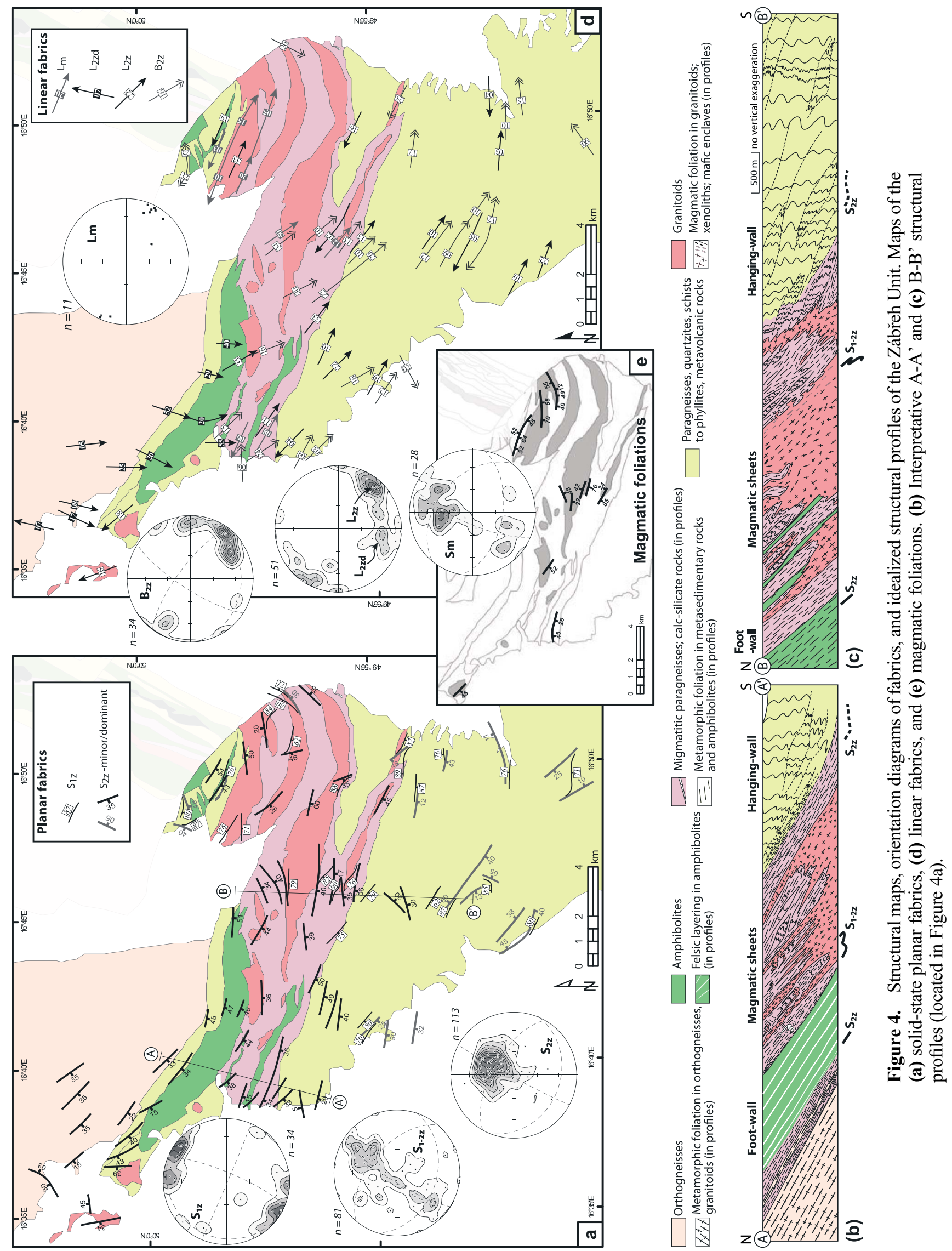



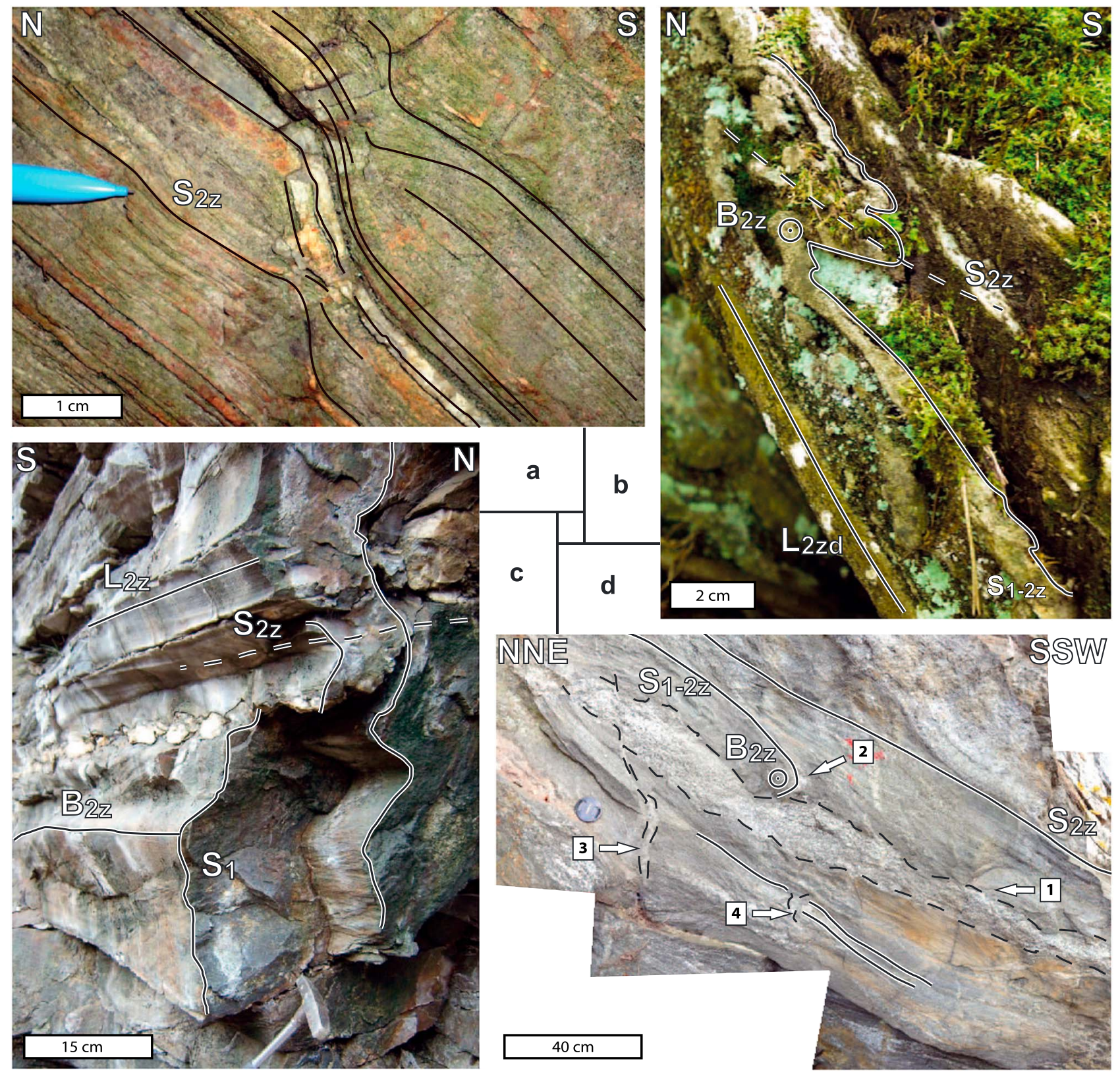

Figure 5. Field photographs showing the main structural features of the Zábřeh Unit (vertical outcrops). (a) Strongly deformed and boudinaged amphibolites in the foot-wall during the $\mathrm{D}_{2 z}$ event which produced the gently south-dipping $\mathrm{S}_{2 z}$. (b) Asymmetrical $\mathrm{F}_{2 z}$ fold with WNW-ESE horizontal fold axis $\mathrm{B}_{2 \mathrm{z}}$ in a calc-silicate multilayer in the foot-wall. The long limb records down-dip $\mathrm{L}_{2 z \mathrm{~d}}$ mineral stretching lineation, subparallel to the orientation of the photograph at high angles to the fold axis $\mathrm{B}_{2 \mathrm{z}}$. (c) Gently folded metapelites in the $S_{2 z}$ axial plane. The mineral lineation $L_{2 z}$ is parallel to the $B_{2 z}$ fold axis (hanging-wall of the ZUS). (d) Cliff oriented approximately in the XZ plane of finite strain ellipsoid shows axial planar $\mathrm{S}_{2 \mathrm{z}}$ cleavage in migmatitic amphibolite gneiss of the ZUS. Veins of plagioclase cumulate are collected in $\mathrm{S}_{2 \mathrm{z}}$ (arrow 1), in the hinge of $\mathrm{F}_{2 \mathrm{z}}$ fold (arrow 2), in hybrid fractures (arrow 3) and in tensional gashes opened perpendicular to $\mathrm{S}_{2 z}$ (arrow 4). Veins present low-strain LT solid-state microstructures. Note that the main vein shows cylindrical pinch-and-swell structures with boudin axes parallel to $B_{2 z}$, into the wall and parallel to the Y-axis.

chloritized biotite aggregates. Magmatic to solid-state deformation along planes parallel to $S_{2 z}$ points to a syn- $D_{2 z}$ magmatic emplacement. Finally, in the OSD core, the orthogneisses show a complete fabric concordance with $\mathrm{D}_{2 \mathrm{z}}$ of the overlying amphibolites of the Zábreh Unit; this is expressed by a several hundred meters wide zone of mylonites whose foliations (parallel to $S_{2 z}$ ) gently dip to the south and carry a strong down-dip stretching lineation (parallel to $\mathrm{L}_{2 \mathrm{zd}}$ ) (Figures $4 b$ and $4 c$ ).

[21] In summary, the contemporaneous, early Carboniferous SMS and ZUS granitoid sheets are syntectonic to $\mathrm{D}_{2 \mathrm{~s}}$ and $\mathrm{D}_{2 \mathrm{z}}$, respectively, with a locally strong solid-state 

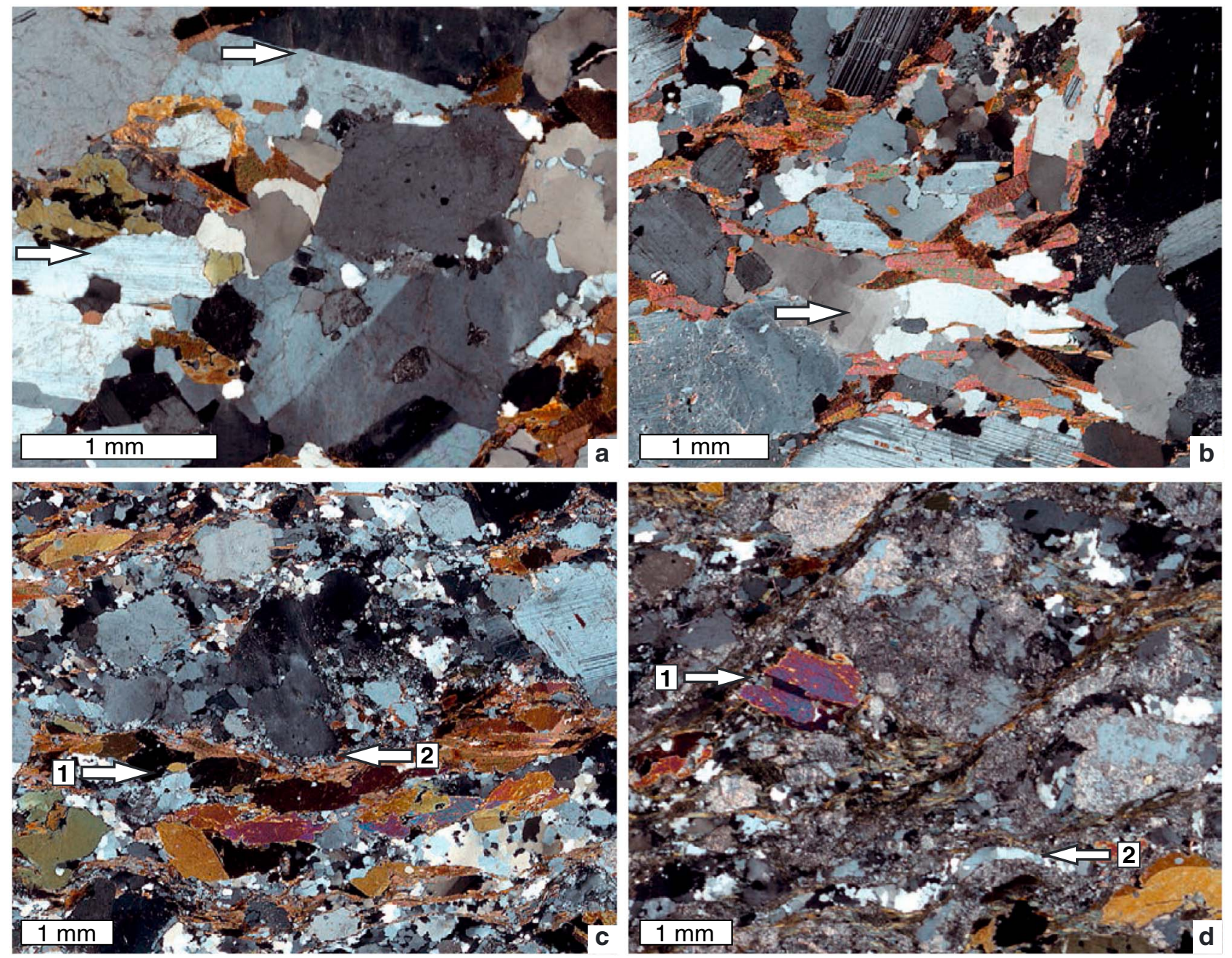

Figure 6. Photomicrographs in cross-polarized light of plutonic microstructures in $\mathrm{K}_{1} \mathrm{~K}_{3}$ plane with $\mathrm{K}_{1}$ parallel to the long side of the picture. (a) Magmatic fabric defined by the orientation of primary plagioclase with twin boundaries of feldspars porphyroclasts (arrows) aligned subparallel to the foliation (specimen \# JL68). (b) Submagmatic microstructure marked by chessboard subgrains (arrow) and grain boundary migration of quartz (specimen \# JL259). (c) HT solid-state microstructure: continuous band of amphiboles and biotites (arrow 1) and "core and mantle" features in plagioclases (arrow 2) (specimen \# JL306). (d) LT solid-state microstructure illustrated by fractured primary minerals (i.e., hornblende, arrow 1), grain size reduction of quartz and formation of an anastomosed foliation of quartz and chlorite (arrow 2) (sample \# JL399).

deformation overprinting a magmatic foliation, and are of broadly similar composition. However, they were emplaced in different settings. The SMS intruded at depth corresponding to $8-10 \mathrm{kbar}$ pressure within the banded amphibolites in the foot-wall of the OSD gneissic core, while the ZUS intruded at 4-6 kbar, in between the gneiss core and foot-wall of the supracrustal rocks of the metamorphic mantle. The inherited pre-intrusive foliation is gently north-dipping in the SMS area $\left(\mathrm{S}_{1 \mathrm{~s}}\right)$ while it is steep and WNW-ESE striking in the ZUS $\left(\mathrm{S}_{1 \mathrm{z}}\right)$. The

Figure 7. Staré Město Sheets (SMS): map of the microstructure records and domains having different AMS types and associated $\mathrm{K}_{1}$ and $\mathrm{K}_{3}$ equal-area plots (lower hemisphere) with $\mathrm{Pj}-\mathrm{T}$ graphs. The fabric (pole of foliation or mineral lineation) of the country rocks is reported in each equal-area plot with the aim to compare field structural and AMS data. Map: the color shading and line fill symbols indicate different AMS types, as discussed in the text; the microstructures of the intrusive rocks, main structural elements in the country rocks and locations of the sampled profiles of the northern part are also reported on the map. $\mathrm{K}_{3}$ equal-area plots and $\mathrm{Pj}$ - $\mathrm{T}$ graphs of the northern part (profiles 1 to 4): (a) western margin marked by a Type I fabric, (b) center, Type III fabric, and (c) eastern margin, Type I fabric. (d) Equal-area plot of $\mathrm{K}_{1}$ for the entire northern part of the SMS. (e) $\mathrm{K}_{1}$ and $\mathrm{K}_{3}$ equal-area plots and Pj-T graphs for the Bielice valley marked by a Type I fabric. (f) $\mathrm{K}_{1}$ and $\mathrm{K}_{3}$ equal-area plots and Pj-T graphs from the central and southern parts marked by Type I and Type II fabrics. Meaning of AMS parameters explained in section 6 


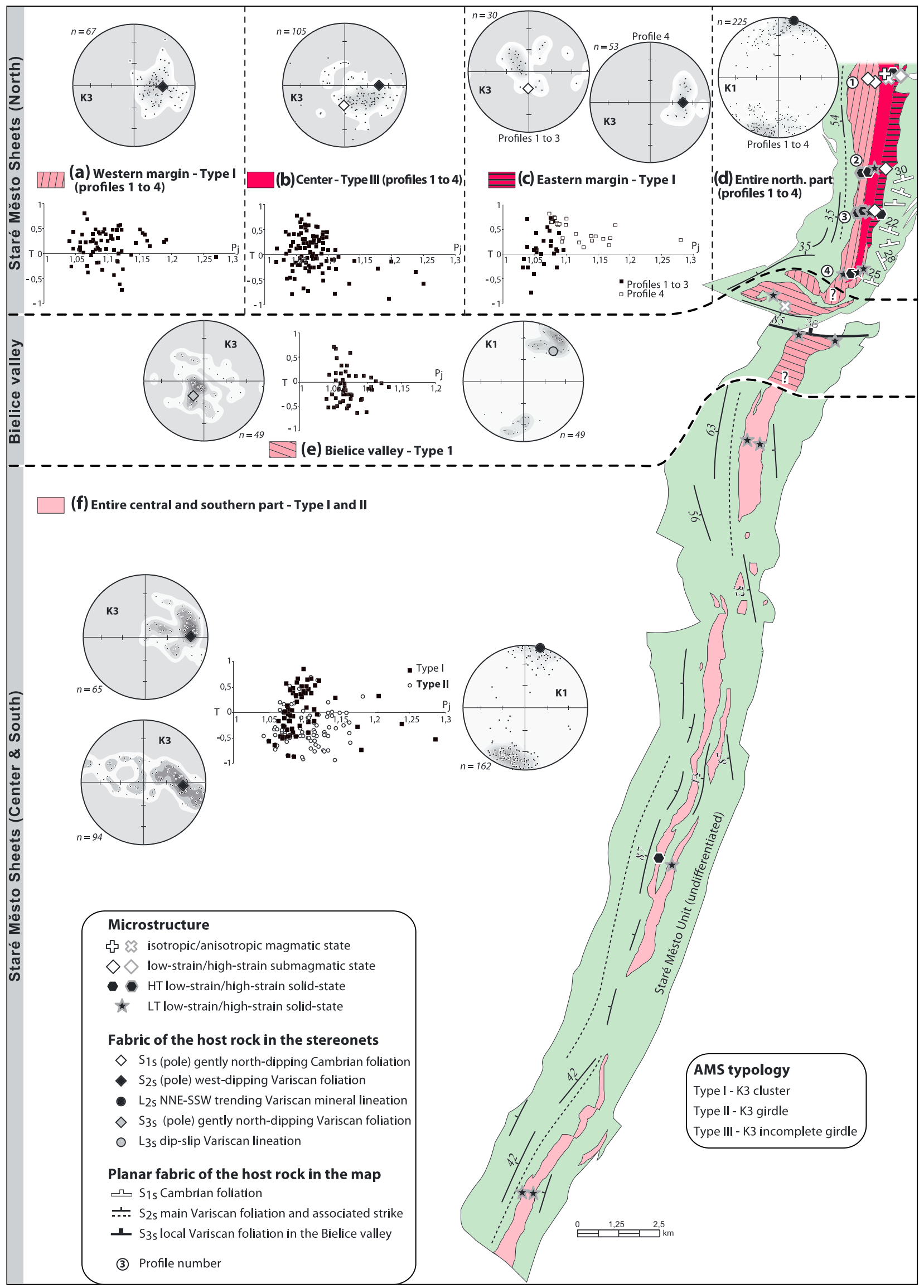

Figure 7. 


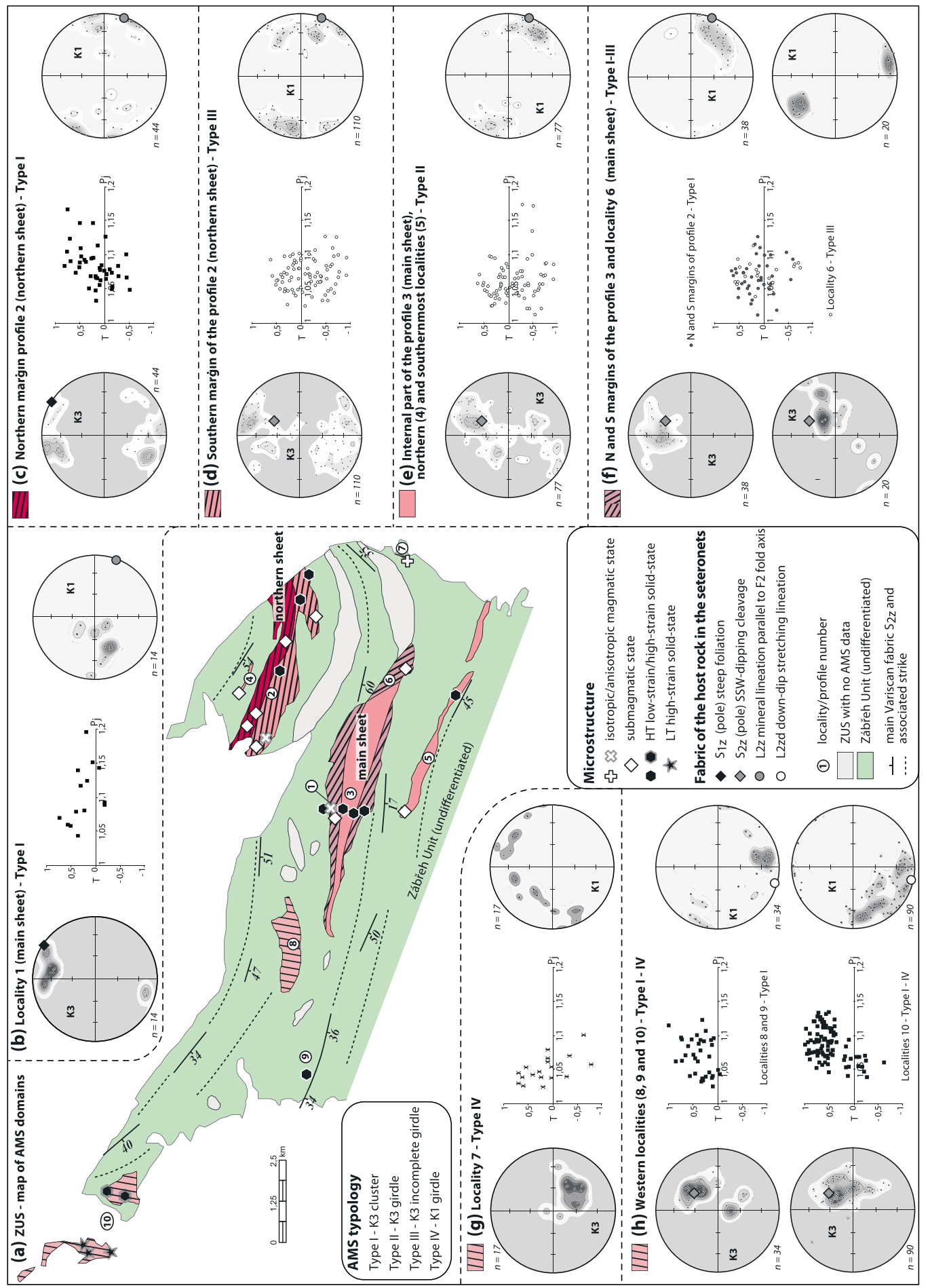

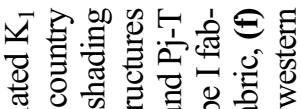

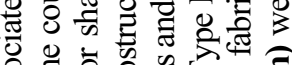

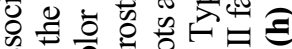

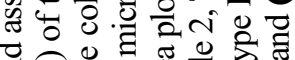
氙 合

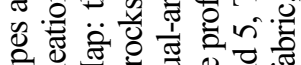

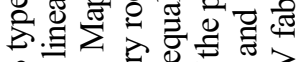
西

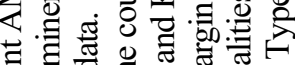

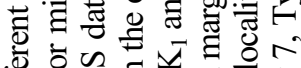
氖

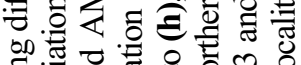

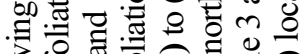
突 言言 जी 速遂畐焉 ․ㅡㅁ은 击

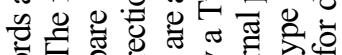

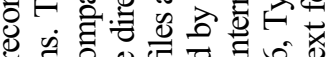

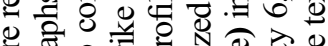

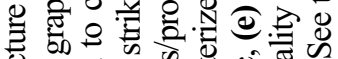

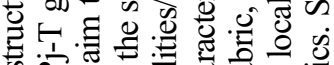

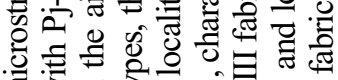

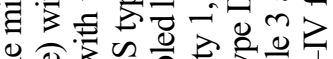

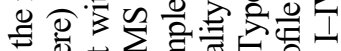

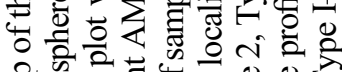

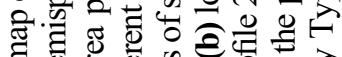

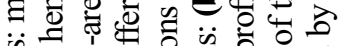

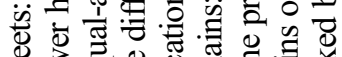
ॠ

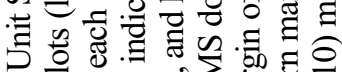

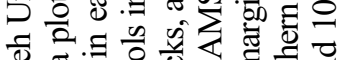

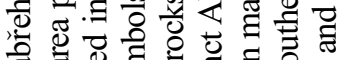

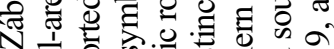

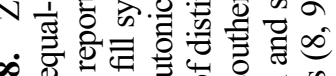

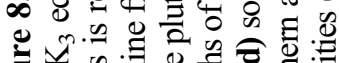

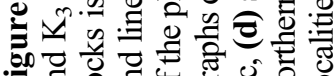

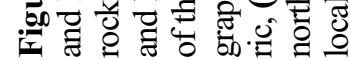


(a)

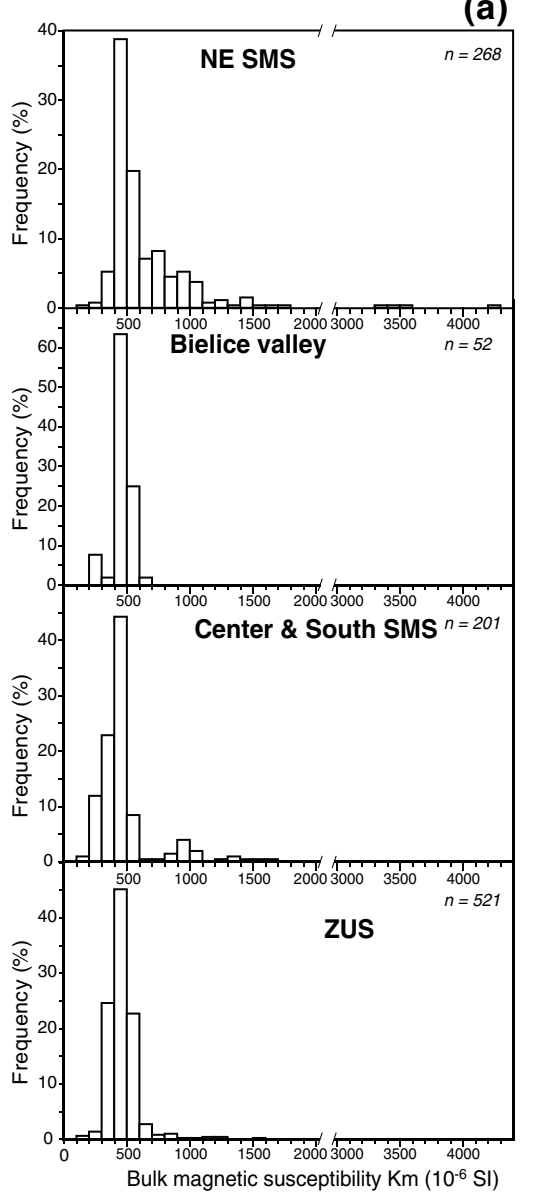

(b)

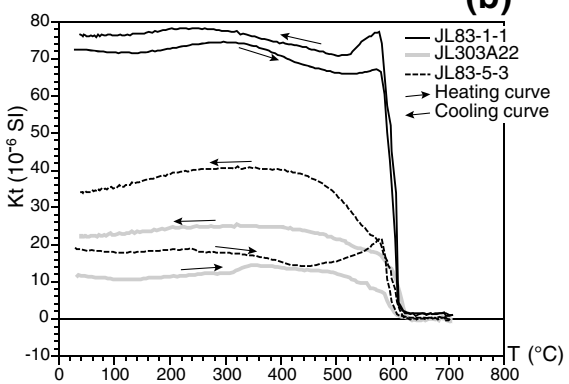

(d)

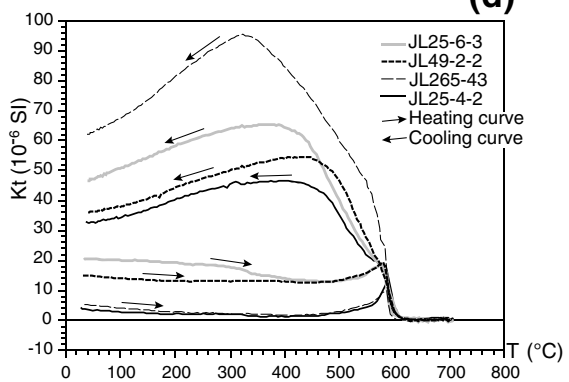

(f)

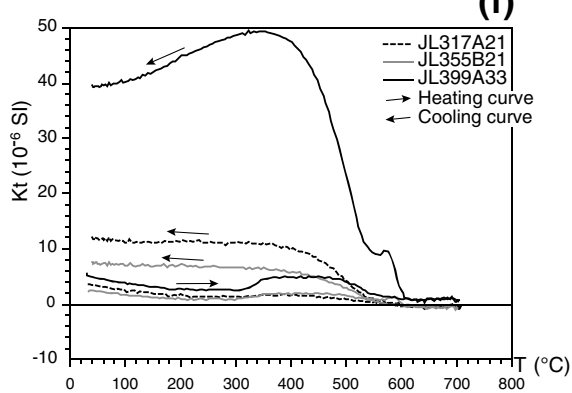

(c)

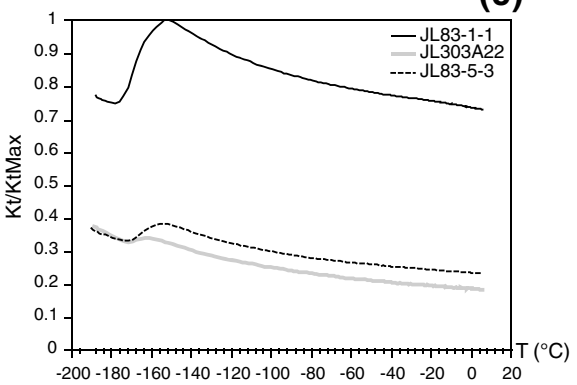

(e)

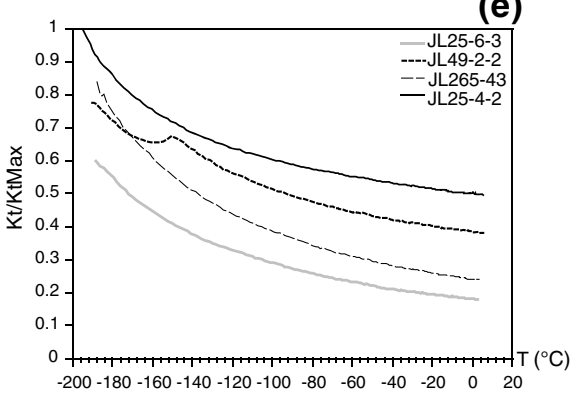

(g)

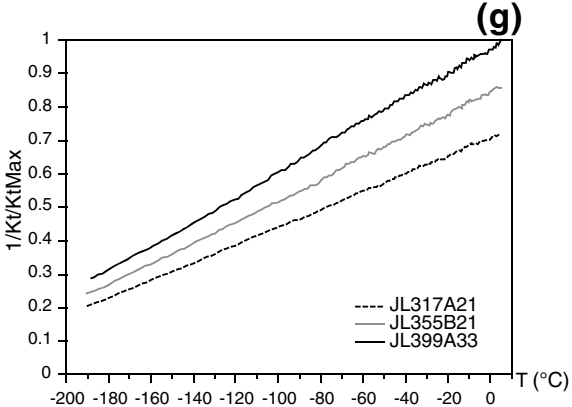

Figure 9. Magnetic mineralogy study results. (a) Distribution of the bulk susceptibility for each of the four zones. (b) to (g), total susceptibility Kt [Jelinek, 1977] is in dimensionless units (in SI) of the order $10^{-6}$. (b) Heating and cooling thermomagnetic curves, and (c) LT curves for specimens where magnetite is without doubt the susceptibility carrier of the AMS. (d) Heating and cooling curves, and (e) LT curves for specimens where the AMS is represented by paramagnetic minerals with a possible subordinate effect of magnetite. (f) Heating and cooling curves and (g) LT curves for paramagnetic specimens.

contact between the SMS and ZUS is characterized by an apparent dextral offset of the ZUS along a ductile greenschist south-dipping normal fault (Figure 1: Bušin Fault) [Franke and Zelazniewicz, 2000], and by a change in strike of the $\mathrm{S}_{1 \mathrm{z}}$ fabric from $\mathrm{WNW}$ to NNE. Within the SMS, textural continuity between the NNE- and EWstriking granitoids suggest that the local $D_{3 s}$ developed along the Bielice valley was active just after $D_{2 s}$, when the magma was not entirely crystallized.

\section{Deformation Microstructures}

[22] The granitoids present a microstructural continuum of low- or high-strain magmatic, submagmatic, hightemperature (HT) and low-temperature (LT) solid-state fabrics at decreasing temperature. The magmatic to submagmatic microstructures are characterized by a shape preferred orientation (SPO) of euhedral feldspars, biotites, and amphiboles. Twin boundaries of feldspar porphyroclasts are often aligned parallel to the foliation, suggesting a lattice preferred orientation (Figure 6a). Magmatic microstructures are also defined by matrix minerals with anhedral shapes, indicating their lack of plastic deformation and SPO. Submagmatic microstructures [Paterson et al., 1989] are represented by the onset of plasticity of quartz having highly lobated boundaries and typical chessboard subgrains indicating temperature of deformation close to solidus, i.e., $\sim 700^{\circ} \mathrm{C}$ [Kruhl, 1996; Stipp et al., 2002] (Figure 6b). Magmatic to submagmatic microstructures are typically developed in the diorites and granodiorites of the core and eastern margin of the northern SMS (microstructure symbols of profiles 1 to 3 in map of Figure 7). In the ZUS, magmatic and low intensity submagmatic microstructures characterize the diorites and granodiorites from the northern margin of the northern and main magmatic sheets (microstructure symbols of profile 2 , locality 4 , and profile 3 , respectively, in Figure 8a). These microstructures are also visible in the southernmost intrusions (profile 5) or in other localities (microstructure symbols of localities 6 and 7 in Figure 8a). 
[23] HT (microstructure symbols in map of Figures 7 and 8a) solid-state microstructures are characterized by dynamic recrystallization of quartz aggregates through grain boundary migration with minor subgrain rotation associated with formation of continuous bands of amphiboles and biotites (Figure 6c). Feldspars with typical "core and mantle" features are usually elongated and form lenses surrounded by recrystallized grains (Figure 6c). High-strain HT solid-state microstructures are typically developed in the granodiorites of the western margin of the northern intrusion of the SMS (microstructure symbols in map of Figure 7), while low-strain ones characterize the south and center of the northern and main sheets of the ZUS (microstructure symbols of profiles 2 and 3, Figure 8a).

[24] LT solid-state microstructures are illustrated by finely recrystallized quartz grains forming anastomosing foliation planes around altered, boudinaged and fractured amphiboles and feldspars (Figure 6d). Primary minerals are altered such as plagioclase into clay, mica, epidote, and hornblende into chlorite, biotite, or tremolite-actinolite (Figure 6d). Typical high-strain greenschist facies mylonitic microstructures are widespread in the E-W trending granodiorites from the Bielice valley (microstructure symbols in map of Figure 7e), in the granodiorites, monzogranites, and plagioclase cumulates from the central and southern areas of the SMS (microstructure symbols in map of Figure $7 \mathrm{f}$ ), and in the granodiorites from the western part of the ZUS (microstructure symbols of Figure 8a).

\section{AMS}

\subsection{Sampling Strategy and Magnetic Measurements}

[25] Measurements of the low-field bulk susceptibility and AMS were performed on 1042 specimens $(2.25 \mathrm{~cm}$ length, $2.5 \mathrm{~cm}$ diameter) from 81 localities (12 to 14 specimens per locality). The samples were drilled with a portable drill, and some large hand specimens were also collected, plastered, and drilled in the laboratory. The magmatic sheets have been systematically sampled along several profiles with a spacing, along strike of the main fabric, of 1 to $10 \mathrm{~km}$, depending on outcrop conditions. The sampling spacing along profiles perpendicular to the strike was approximately $100-200 \mathrm{~m}$. In order to determine the contribution of specific minerals to the bulk rock susceptibility, the magnetic minerals carrying the AMS were investigated through measurement of the temperature variation of the mean susceptibility on powder specimens using the CS-L cryostat Apparatus and the MFKA-FA Kappabridge at AGICO (Brno, Czech Republic). The AMS was measured with DIGICO instruments at the Institut de Physique du Globe (Strasbourg, France). Statistical processing and evaluation of data were carried out using the ANISOFT 42 Program [Chadima and Jelínek, 2008] and standard AMS parameters were calculated according to Jelinek [1978]. The mean susceptibility calculated as $K_{m}=\left(K_{1}+K_{2}+K_{3}\right) / 3$ where $K_{1} \geq K_{2} \geq K_{3}$ are the principal axes of the susceptibility ellipsoid. The degree of susceptibility anisotropy calculated as $P j=\exp \sqrt{\left[\left(\ln K_{1}-\ln K_{m}\right)^{2}+\left(\ln K_{2}-\ln K_{m}\right)^{2}+\left(\ln K_{3}-\ln K_{m}\right)^{2}\right]}$ expresses the departure from an undeformed, spherical AMS ellipsoid $(\mathrm{Pj}=1)$. The shape parameter $T=2 \ln \left(K_{2} / K_{3}\right) /$ $\ln \left(K_{1} / K_{3}\right)-1$ quantifies the shape of the magnetic ellipsoid, being linear when $-1<\mathrm{T}<0$ and planar when $0<\mathrm{T}<1$. The orientation of the AMS is characterized by magnetic foliations, equivalent to the $\mathrm{K}_{1}-\mathrm{K}_{2}$ plane and magnetic lineations, defined as directions parallel to $\mathrm{K}_{1}$.

\subsection{Magnetic Mineralogy}

[26] The mean bulk susceptibility is relatively high and homogeneous for the whole series of intrusions with an average value around $450 * 10^{-6}$ SI (Figure 9a). Only in the northernmost parts of the SMS, the magnetic susceptibility shows a large spread ranging from 300 to $1500 * 10^{-6}$ SI. The diorites (5\% of the measured population) display bulk susceptibilities around $370 * 10^{-6} \mathrm{SI}$, the granodiorites, and monzogranites (respectively, $88 \%$ and $6 \%$ of the measured population) about $430 * 10^{-6} \mathrm{SI}$, and the plagioclase cumulates ( $\sim 1 \%$ of the measured population) around $260 * 10^{-6}$ SI. Thermomagnetic curves have been established for a selection of 10 samples according to their mean bulk susceptibility values. The thermomagnetic curves show that the first set of specimens (samples \# JL83-1-1, JL303A22 and JL83-5-3, characterized by $\mathrm{Km}>800 * 10^{-6} \mathrm{SI}$, representing $6 \%$ of the measured population) is marked by heating and cooling curves that are very close to each other, and by a LT curve which contains a well-defined Verwey transition (Figures 9b and 9c). In these specimens, magnetite is the principal susceptibility carrier. By contrast, cooling curves of specimens \# JL25-6-3, JL49-2-2, JL265-43, and JL25-4-2 yield significantly higher susceptibilities than heating curves (Figure 9d), and the LT curves mostly define paramagnetic hyperbola (Figure 9e). In these specimens, susceptibility is predominantly due to the paramagnetic minerals, even though a subordinate effect of magnetite could be present. These two first sets of specimens are characterized by a Curie temperature close to $580^{\circ} \mathrm{C}$ (Figures 9b and 9d), which is typical of a nearly pure magnetite (i.e., titanomagnetite with a very low Ti content) [Lattard et al., 2006 and references therein]. Specimens \# JL317A21 and JL355B21 show heating and cooling curves that are rather close together with no magnetite Curie temperature on the heating curves (Figure 9f); their LT curves do not contain the Verwey transition, but show clearly defined paramagnetic behavior (Figure 9g). The same holds for the specimen \# JL399A33 although the cooling curve yields much higher susceptibilities than the heating curve (Figure 9f). Such thermomagnetic data indicate that virtually no magnetite is present in these samples. In conclusion, except for a few samples the thermomagnetic data point to the dominance of the paramagnetic minerals, here represented by biotite and hornblende.

\subsection{Magnetic Fabrics}

[27] The magnetic data reveal a well-defined magnetic lineation $\left(\mathrm{K}_{1}\right.$ axis) which is generally parallel to the strike of the magmatic sheets and to the trend of the mineral lineation. According to the distribution of the $\mathrm{K}_{3}$ axis (the pole to the magnetic foliation, $\mathrm{K}_{1}-\mathrm{K}_{2}$ ) in equal-area projections, three types of fabrics can be distinguished (Type $\mathrm{I}-\mathrm{K}_{3}$ clusters, Type II- $\mathrm{K}_{3}$ girdles, and Type III-incomplete $\mathrm{K}_{3}$ girdles) themselves related to systematic variations in fabric symmetry and intensity (Figures 7 and 8). $\mathrm{K}_{3}$ girdle means that $\mathrm{K}_{1}-\mathrm{K}_{2}$ planes have a single intersection, or define a fold. A fourth fabric type (Type IV), marked by girdle distributions of $\mathrm{K}_{1}$ directions, can also be recognized (Figures $8 \mathrm{~g}$ and $8 \mathrm{~h}$ ). It is 
associated with a neutral to oblate shape of AMS ellipsoid and represents a well spread distribution of $\mathrm{K}_{1}$ lineation within the $\mathrm{K}_{1}-\mathrm{K}_{2}$ foliation.

\subsubsection{SMS}

[28] In the northern part of the SMS, four cross sections were investigated (Figure 7). Three of them (profiles 2 to 4) were already studied by Parry et al. [1997] but because of the small number of specimens, the sites were resampled in order to keep a statistical consistency of our study. The western margin of the SMS (Figure 7a) yields a ubiquitous cluster-Type I fabric, marked by west-dipping magnetic foliations parallel to $\mathrm{S}_{2 \mathrm{~s}}$, and by dominantly oblate ellipsoids with a relatively strong yet variable degree of susceptibility anisotropy $(\mathrm{Pj}=1.04$ to 1.2). The center of the intrusion shows an incomplete girdleType III fabric consistent with a gentle north-dipping to WNW-dipping foliation (Figure 7b). The north-dipping orientation is similar to the one of $\mathrm{S}_{1 \mathrm{~s}}$. The AMS ellipsoids are oblate to neutral, and the degree of anisotropy spreads from $\mathrm{Pj}=1.02$ to 1.25 . Finally, the eastern margin has a Type I fabric, either marked by southeast-gently-dipping foliations, neutral to oblate shapes of ellipsoids and a weak degree of anisotropy $(\mathrm{Pj}=1.03$ to 1.10 , profiles 1 to 3 , Figure $7 \mathrm{c})$, or west-dipping foliations, oblate AMS ellipsoids, and a relatively strong degree of anisotropy with $\mathrm{Pj}$ parameter ranging from 1.07 to 1.18 (profile 4, Figure $7 \mathrm{c}$ ). These four northern profiles are marked by a ubiquitous NNE-SSW trending lineation (Figure 7d), which is broadly parallel to the mineral lineation of the host rocks $\mathrm{L}_{2 s}$ and the intrusions $\mathrm{L}_{\mathrm{m}}$ and perpendicular to the incomplete girdle-Type III observed in the center of the intrusion (Figure $7 \mathrm{~b}$ ). The foliations along the E-W trending magmatic sheets at the southern termination of the main granodiorite sheet (Bielice valley, Figure 7e) have gentle NNE dips, and down-dip lineations, compatible with mesoscopic fabric measurements. The Type I fabrics have close to neutral shapes with a slight preference for prolate fabrics and low degree of anisotropy $(\mathrm{Pj}=1.04-1.13)$.

[29] The discontinuous granitoid sheets that outcrop in the central and southern parts of the SMS (Figure 7f) were sampled along discrete localities. They display strong maxima of NNE-trending lineations and either clusters of steeply westdipping foliations (Type I, Figure 7f, upper equal-area plot), oblate to prolate fabrics and a weak degree of anisotropy $(\mathrm{Pj}=1.05-1.12)$ or an $\mathrm{E}-\mathrm{W}$ trending girdle of foliations (Type II, Figure 7f, lower equal-area plot) associated with a generally prolate fabric of variable intensity $(\mathrm{Pj}=1.04-1.16)$. The cluster-Type I fabrics are observed in strongly deformed individual magmatic pods or along western margins of hundreds meter-thick sheets while girdle-Type II fabrics prevail through the central domain and along eastern margins of hundreds meter-thick sheets.

\subsubsection{ZUS}

[30] Generally, magnetic foliations and lineations of the ZUS are subparallel to the magmatic contacts and to the $\mathrm{L}_{2 z}$ and $\mathrm{L}_{\mathrm{m}}$ mineral lineations and $\mathrm{B}_{2 z}$ fold axes measured in the field (Figure 8). Type I - III AMS fabrics are dominant over the whole set of intrusions, associated with steep to flat, roughly E-W striking magnetic foliations and NE-SW to NW-SE trending magnetic lineations.

[31] One AMS fabric is not consistent with the typology presented in this section. Located at the northern margin of the main sheet (locality 1, north of the main sheet in profile 3 , Figure $8 \mathrm{a}$ ), it is characterized by steep E-W trending foliations (parallel to the local $\mathrm{S}_{1 \mathrm{~s}}$ ), steep lineations plunging to the west, neutral to oblate shapes and variable anisotropy degrees of the AMS ellipsoids ranging from 1.04 to 1.2 (Figure $8 \mathrm{~b}$ ). Type I fabric, marked by steep E-W trending foliations and two subhorizontal lineation maxima, one E-W and the other NW-SE subparallel to $\mathrm{B}_{2 \mathrm{z}}$ fold axis develops at the northern margin of the northern sheet (profile 2 in Figure 8a) and is associated with neutral to oblate strain and an anisotropy degree ranging from $\mathrm{Pj}=1.03$ to 1.15 (Figure $8 \mathrm{c}$ ). The southern margin of the northern sheet (i.e., profile 2 in Figure 8a) displays a Type III fabric marked by an incomplete NNE-SSW trending girdle of magnetic foliations with steep maxima, several lineation maxima defining a broad region centered around shallowly plunging E-W lineations and dominantly neutral to prolate AMS ellipsoids of low intensity $(\mathrm{Pj}=1.02-1.12$, Figure $8 \mathrm{~d})$. The internal part of the main sheet (profile 3 ), the northernmost granodiorite body (locality 4), and the southernmost granodiorite sheet (at locality 5, Figure 8a) show excellent Type II patterns defining a subvertical great circle trending NE-SW, a neutral to prolate magnetic ellipsoid and low anisotropy degrees $(\mathrm{Pj}=1.01-1.1$, Figure $8 \mathrm{e})$. The AMS axes distribution is consistent with a subhorizontal axis of rotation trending WNW-ESE, subparallel to the magmatic lineation $\mathrm{L}_{\mathrm{m}}$ and the $\mathrm{B}_{2 \mathrm{z}}$ fold axis. Type I-III fabrics are prevailing along both the northern and southern margins of the main magmatic sheet (profile 3, Figures $8 \mathrm{a}$ and $8 \mathrm{f}$ ) and are marked by N-S incomplete girdles of foliations with a strong south-dipping submaximum and WNW-ESE trending lineations which are parallel to the $\mathrm{L}_{2 z}$ and $\mathrm{L}_{\mathrm{m}}$ mineral lineation and $\mathrm{B}_{2 \mathrm{z}}$ fold hinge. The magnetic ellipsoid is neutral to slightly oblate, with $\mathrm{T}$ varying from 0.5 to -0.5 and the degree of anisotropy $\mathrm{Pj}$ ranging from 1.01 to 1.13 (Figure 8f). Type III patterns develop within narrow parts of the main intrusion (at locality 6, Figures $8 \mathrm{a}$ and $8 \mathrm{f}$ ), which separate the region marked by eastern WNW-ESE striking magmatic sheets and the region dominated by western WSW-ENE striking sheets. The AMS fabric is characterized by a main submaximum of southdipping foliations and a strong cluster of NNW-SSE trending magnetic lineations. The magnetic ellipsoid is represented by neutral to prolate shapes with a low degree of anisotropy $(\mathrm{Pj}=1.01-1.13$, Figure $8 \mathrm{f})$. A small NE-SW trending intrusion located in the southeast of the main body (locality 7 , Figures $8 \mathrm{a}$ and $8 \mathrm{~g}$ ) shows a Type IV pattern marked by a strong maximum of $\mathrm{K}_{3}$ corresponding to foliations moderately dipping to the NW, and by a girdle of lineations in the plane perpendicular to $K_{3}$. The shape of the magnetic ellipsoid is oblate and the anisotropy degree low, with $\mathrm{Pj}$ parameter ranging from 1.02 to 1.1 (Figure $8 \mathrm{~g}$ ).

[32] The western termination of the ZUS is marked by two outcrops of magmatic rocks (localities 8 and 9, Figure 8a) and two large quarries (locality 10, Figure $8 \mathrm{a}$ ). The southernmost bodies, at localities 8 and 9 (Figure 8h) show strong maximum of $\mathrm{K}_{3}$ consistent with foliations moderately dipping to the SW and a subordinate maximum of gently north-dipping foliations. The $\mathrm{K}_{1}$ axes also show a bimodal distribution with a strong maximum of slightly plunging to the SSE or less importantly to the west. The magnetic ellipsoid is neutral to oblate, and $\mathrm{Pj}$ values range from 1.02 to 1.12 . The northern magmatic outcrops, at locality 10 (Figure $8 \mathrm{~h}$ ) show a Type $\mathrm{I}-\mathrm{IV}$ pattern marked by a wide $\mathrm{K}_{3}$ maximum corresponding to foliations mostly dipping to the SW under gentle to 
(0001) $\{10 \overline{1} 0\} \quad\{11 \overline{2} 0\} \quad(0001) \quad\{10 \overline{1} 0\}$

$\{11 \overline{2} 0\}$

(a) Staré Město and Zábřeh Unit Sheets - magmatic to submagmatic microstructures

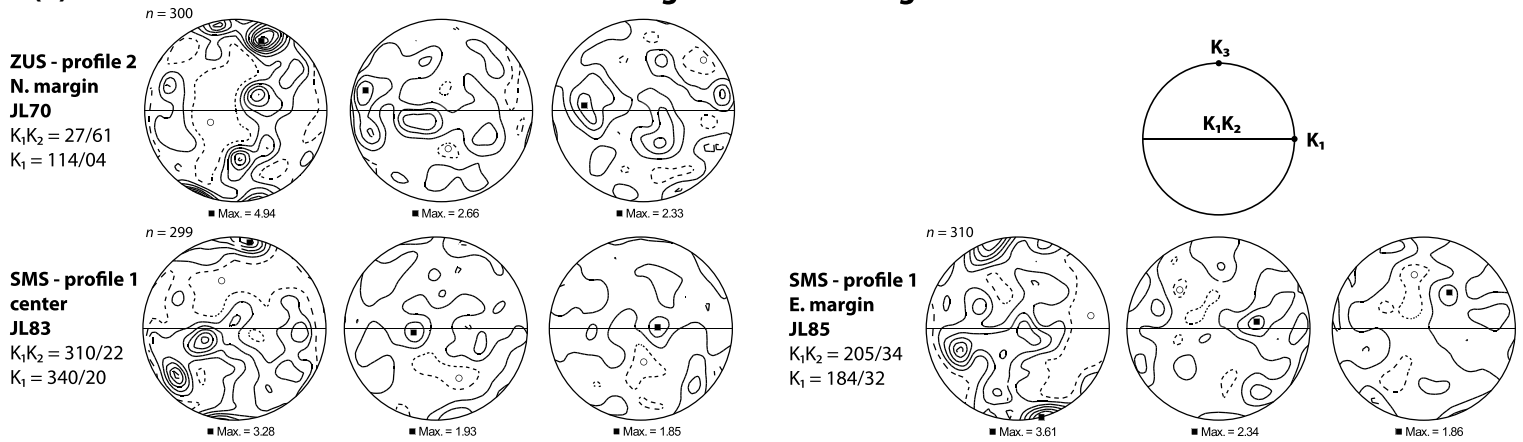

(b) Staré Město Sheets \& Bielice valley - solid-state microstructures

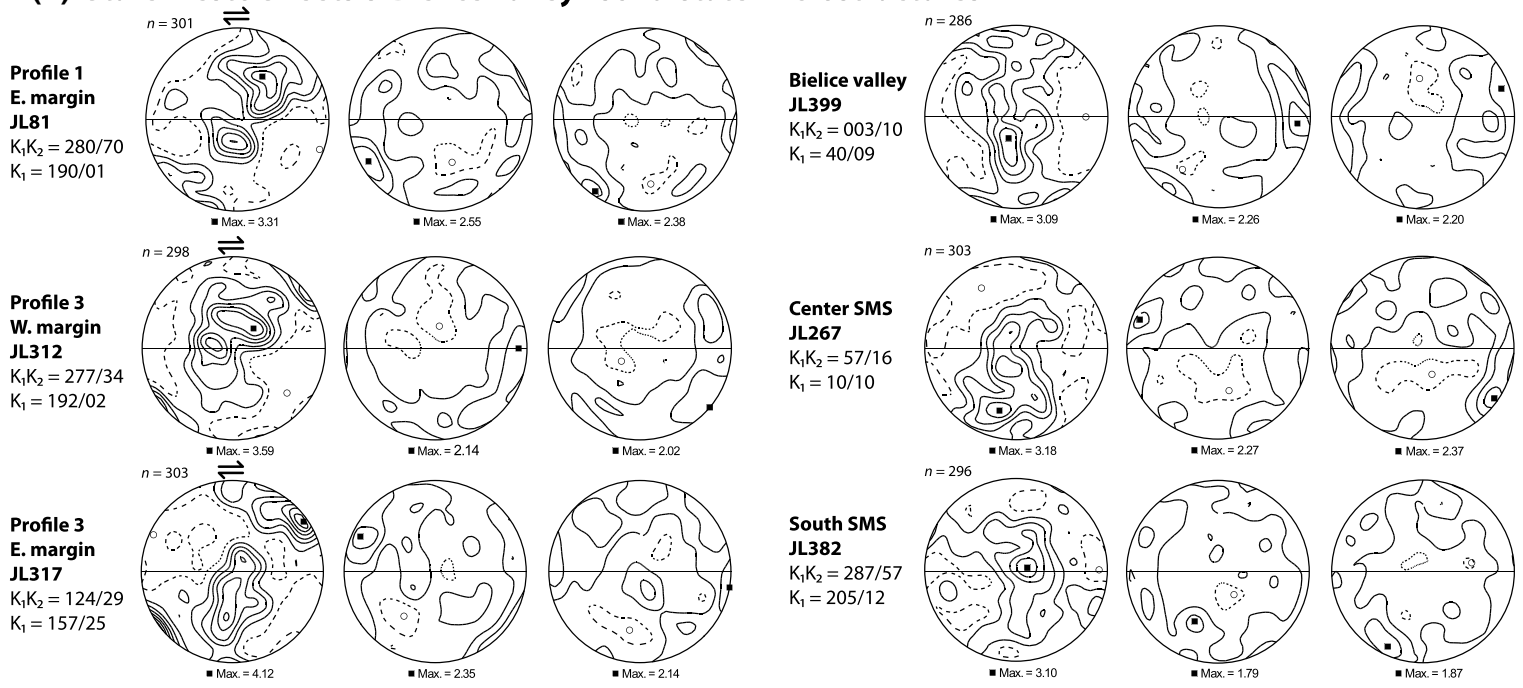

(c) Zábřeh Unit Sheets - solid-state microstructures
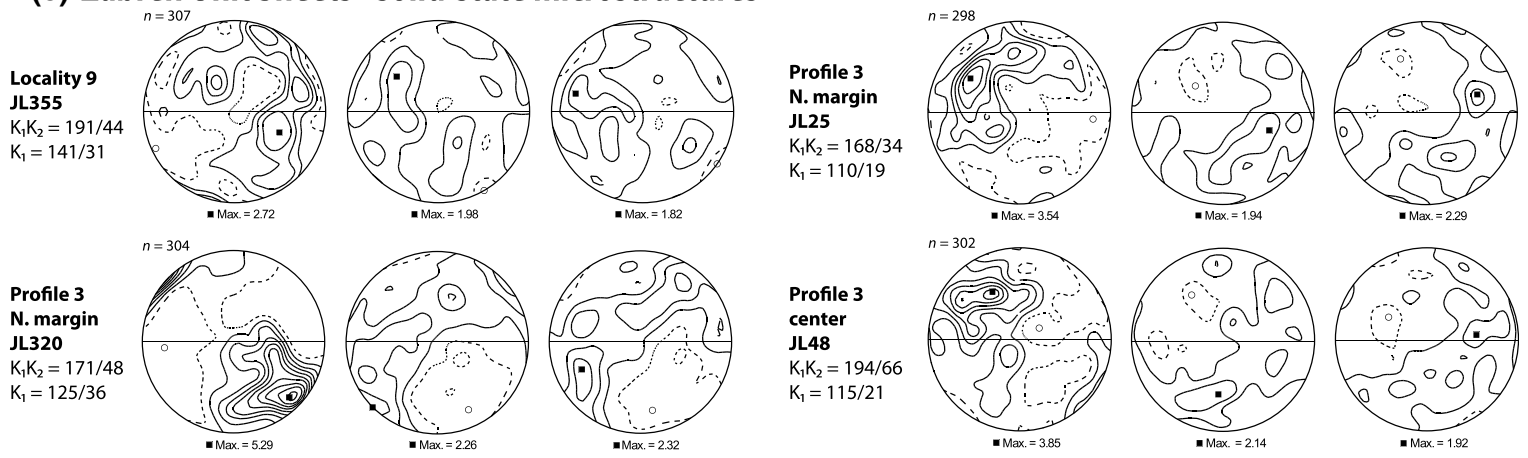

Figure 10. Crystallographic orientation of quartz grains measured by Electron Back Scattered Diffraction (EBSD) in the $\mathrm{K}_{1} \mathrm{~K}_{3}$ sections of AMS ellipsoid (see Figures 7 and 8 for location of localities and profiles). The equal-area plots (lower hemisphere) represent the [c-axes] (poles to base (0001)), $<m$-axes $>$ (poles to the first-order prism $(10-10)$ ) and $<a$-axes $>$ (poles to the second-order prism (11-20)). The bold numbers indicate the sample name. The orientation of the magnetic foliation $\mathrm{K}_{1} \mathrm{~K}_{2}$ plane (i.e., the equatorial line in the equal-area plot), the magnetic lineation $\mathrm{K}_{1}$ and the number of analyzed grains $(n)$ are also reported. Contours refer at interval of 0.5 time uniform density. Maximum densities are marked on the bottom center of each equal-area plot. The dashed line represents the lowest contour level, and the white circle corresponds to the minimum density value. The arrows indicating sense of shear are determined from inclination of the girdles with respect to the magnetic foliation. (a) Staré Město and Zábřeh Unit Sheets, magmatic to submagmatic microstructures. (b) Staré Město Sheets and Bielice valley, solid-state microstructures. (c) Zábřeh Unit Sheets, solid-state microstructures. The CPO of the samples \# JL355, JL320, JL48, and JL25 are investigated in Figure 11. See text for the equal-area plots description and interpretation. 


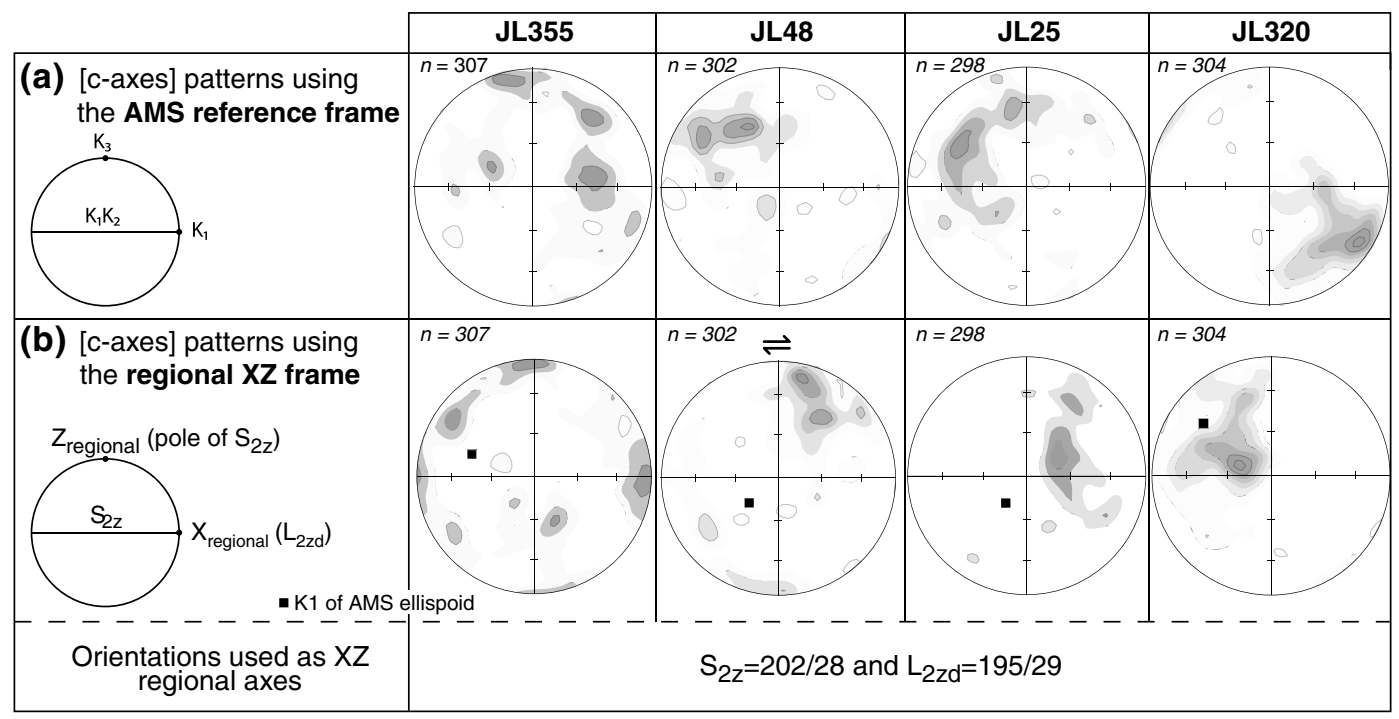

Figure 11. Rotation of c-axes of quartz from (a) the $\mathrm{K}_{1} \mathrm{~K}_{3}$ reference frame to (b) the $\mathrm{XZ}$ regional frame operated to solve obliquities for the samples \# JL355, JL48, JL25, and JL320. The EBSD data are represented in lower-hemisphere equal-area plot. See text for details.

moderate angles, and a girdle of $\mathrm{K}_{1}$ corresponding to southwestward plunging lineations; the magnetic ellipsoid is dominantly oblate, and its anisotropy degree ranges from 1.04 to 1.14 .

\section{Quartz Fabrics}

[33] The microstructural evolution of magmatic, submagmatic, HT, and LT solid-state fabrics with decreasing temperature presented in section 5 has been correlated with measurements of crystallographic preferred orientation (CPO) of quartz, in order to characterize the deformation regime, flow kinematics and conditions of granitoid crystallization, and syn-deformational cooling with respect to the thermal environment of the host rock [Paterson et al., 1989; Gapais, 1989; Tribe and D'Lemos, 1996; Stipp et al., 2002]. Sixty thin sections were cut parallel to the $\mathrm{K}_{1} \mathrm{~K}_{3}$ plane of the AMS ellipsoid $\left(\mathrm{K}_{1}\right.$ and $\mathrm{K}_{3}$ are the maximum and least axes of the AMS ellipsoid, respectively), which is the ideal section to determine the CPO of quartz assuming $\mathrm{K}_{1}$ and $\mathrm{K}_{3}$ are collinear with the $\mathrm{X}$ and $\mathrm{Z}$ axes of the bulk deformation, respectively [Bouchez, 1997; Benn, 2009] (see section 6). Deformation microstructures and textures were studied by optical and SEM microscopy. Crystallographic orientations of quartz from 15 selected thin sections were acquired with a scanning electron microscope CamScan3200 in the Czech Geological Survey in Prague using the electron back-scattered diffraction (EBSD) technique. The EBSD patterns were indexed with the HKL Channel 5 software. Diffraction patterns were measured at $20 \mathrm{kV}$ accelerating voltage, 5nA probe current, and a working distance ranging from 21 to $42 \mathrm{~mm}$. The procedure was carried out in manual mode in order to avoid multiple measurements on a single grain, and only well-fitted data were used.

[34] The quartz grains from magmatic and submagmatic microstructures display several and weak submaxima of c-axes (Figure 10a), drawing either an ill-defined cross-girdle perpendicular to the magnetic foliation (specimen \# JL70), or weak maxima at the periphery of the equal-area plot and close to the foliation (specimens \# JL83 and JL85). Such patterns point to a weak activity of basal $<\mathrm{a}>$ slip system and to possible activity of prism $<\mathrm{c}>$ systems for c-axes close to $K_{1}$.

[35] The solid-state microstructure of the SMS and ZUS show distinct patterns of quartz c-axes. In the SMS, a strong maximum of c-axes is located close to the center of the equal-area plot, at about $30^{\circ}$ from the periphery, and along the periphery of the diagram, always at high angle to the foliation plane (samples \# JL81, JL312, JL317, JL399, JL267, and JL382 in Figure 10b). These patterns can be considered as oblique single girdles or ill-defined Type 1 cross-girdles [Lister and Hobbs, 1980] with opening angles up to $45^{\circ}$ with respect to the $\mathrm{K}_{2} \mathrm{~K}_{3}$ plane. Such c-axes patterns are commonly interpreted as a result of combined activity of prism $<\mathrm{a}>$ and rhomb $<\mathrm{a}+\mathrm{c}>$ slip systems with a variable contribution of basal $<\mathrm{a}>[$ Schmid and Casey, 1986]. The inferred dextral senses of shear deduced from macroscopic observations of shear bands and asymmetrical amphibole clasts agree with these c-axes patterns.

[36] In contrast, in the ZUS, the c-axes patterns of quartz show maxima which did not produce any obvious pattern when rotated into the magnetic foliation [Passchier and Trouw, 2005] (Figures 10c and 11a). As a matter of fact, the kinematic frame of the samples from the ZUS as defined by $\mathrm{K}_{1} \mathrm{~K}_{2} \mathrm{~K}_{3}$, does not correspond to that responsible for plastic deformation of quartz. The c-axes patterns of the ZUS are more easily interpreted by rotating the equal-area plots into the regional $\mathrm{XZ}$ reference frame in which $\mathrm{X}$ is defined by $L_{2 z d}$ and $Z$ defined as the pole of $S_{2 z}$. Equal-area plots resulting from such a rotation are shown in Figure 11b (specimens \# JL355, JL48, JL25 and JL320). The c-axis pattern of specimen \# JL355, with its wide maximum located close to the $\mathrm{L}_{2 \mathrm{zd}}$ lineation within the foliation points to the activity of prism $<\mathrm{c}>$ which is consistent with the HT solid-state microstructure of the specimen. In specimen \# JL48 which displays a HT solid-state microstructure, the c-axes form a maximum close to the periphery of the diagram at $30^{\circ}$ from $\mathrm{Z}$, a pattern commonly interpreted as 


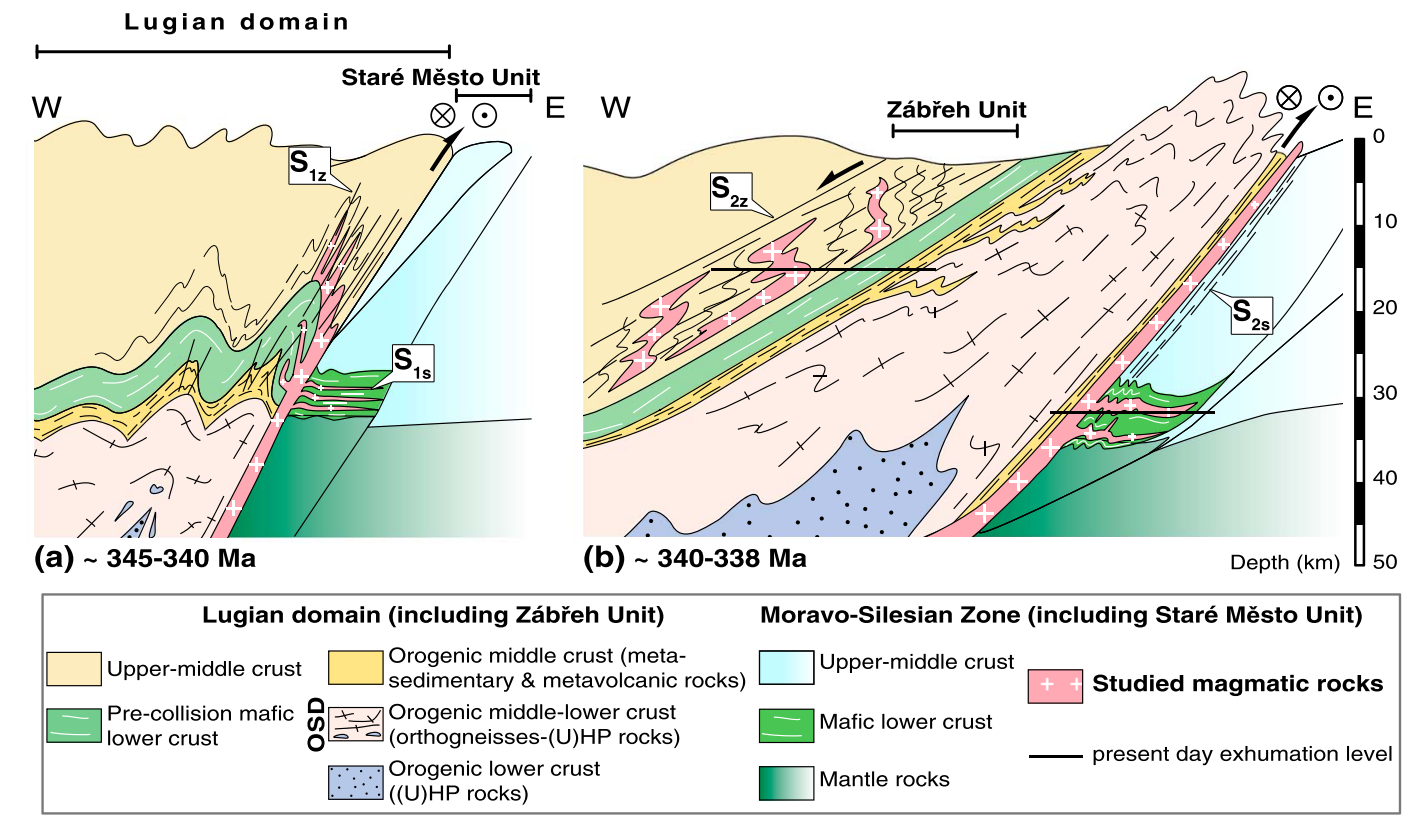

Figure 12. Idealized sketch model of the magmatic sheet emplacement in the frame of the evolution of the Orlica-Śnieżnik Dome.

due to the activity of basal $<\mathrm{a}>$ plus rhomb $<\mathrm{a}+\mathrm{c}>$ during dextral shear [Schmid and Casey, 1986]. In specimens \# JL25 and JL320, the strong maxima close to the center of the diagram call for $\mathrm{c}$-axis incomplete girdles resulting from dominant prism $<\mathrm{a}>$ slip. Such reconstructed pole plots show that the plastic deformation of quartz is interpretable using the regional $\mathrm{L} 2_{\mathrm{zd}}$ as $\mathrm{X}$, meaning that the $\mathrm{L}_{2 \mathrm{z}}$ orientation is not the main direction of tectonic transport in the ZUS. The observed asymmetries allow to infer a top-to-the-SSW sense of shear for the ZUS, compatible with kinematic criteria in the foot-wall gneisses of the OSD [Mazur et al., 2005].

\section{Discussion}

[37] The tectonic significance of the distinct deformation events and relationships between the country rocks and the intrusions will be integrated into the geodynamic evolution of the OSD. Then, the deformation record of the host rockmagma systems will be discussed with the aim to propose mechanisms of emplacement of the SMS and ZUS which will be tested by the internal fabric records. Finally, the inferred deformation superimpositions will be numerically modeled to simulate the variations in shape and degree of anisotropy of the AMS ellipsoid.

\subsection{Significance of Deformation Events in the Frame of the OSD}

\subsubsection{Staré Město Unit}

[38] As already concluded by Parry et al. [1997], the WNW-dipping flow plane bearing a subhorizontal NNESSW trending lineation recorded by the studied magmatic sheets favors a model of dextral simple shear-dominated transpression. The collinear fold axis $\mathrm{B}_{2 \mathrm{~s}}$ and stretching lineation $\mathrm{L}_{2 \mathrm{~s}}$ suggest strain partitioning into simple shear along weak $\mathrm{S}_{2 \mathrm{~s}}$ planes and pure shear in more competent lithologies where $\mathrm{F}_{2 \mathrm{~s}}$ folds are preserved. The compatibility between the $\mathrm{D}_{2 \mathrm{~s}}$ fabric elements of the Staré Město Unit with those of the gneisses of the OSD indicates juxtaposition of these two orogenic units at early Carboniferous time during WNW-ESE horizontal shortening [Chopin et al., 2012a]. However, this deformation was mainly coaxial in the core of the OSD [Skrzypek, et al., 2011a; Chopin et al., 2012a; Štipská et al., 2012]. Our data show that mechanical coupling between the SMS and their country rocks was important in the southern and central parts of the Staré Město Unit (Figure 2d) and low in the northern part, where the SMS is the main decoupling horizon (Figure $2 b$ ). The northern SMS juxtaposed the eastern midcrustal lithologies $(8-10 \mathrm{kbar}$ in the banded amphibolites, Baratoux et al. [2005] and Lexa et al. [2005]) with the western orogenic infrastructure of the OSD (18 kbar in felsic granulites, Stipská et al. [2004]). It is suggested that this juxtaposition occurred because the SMS localized dextral transpression and enhanced oblique thrusting of the OSD over the Staré Město Unit heterogeneously reworking relics of Cambrian shallow-dipping anisotropy $\mathrm{S}_{1 \mathrm{~s}}$.

[39] The greenschist facies, gently NNE-dipping, synmagmatic high-strain zone $\mathrm{D}_{3 \mathrm{~s}}$ of the Bielice valley bears a mineral lineation $\mathrm{L}_{3 \mathrm{~s}}$ which is parallel to the regional one $\mathrm{L}_{2 \mathrm{~s}}$. This implies that $D_{2 s}$ and $D_{3 s}$ share the same elongation axis. Therefore, it is suggested that $\mathrm{D}_{3 \mathrm{~s}}$ originated by an orthogonal switch in shortening direction from horizontal to vertical during progressive vertical loading of the lower crustal material of the OSD over the Staré Město Unit.

\subsubsection{Zábřeh Unit}

[40] The $\mathrm{D}_{1 \mathrm{z}}$ deformation produced a steep WNW-ESE striking metamorphic foliation which is parallel to the margin of the OSD core. $\mathrm{S}_{1 \mathrm{z}}$-parallel sills attest that $\mathrm{D}_{1 \mathrm{z}}$ is pre-intrusive in age and might be either Proterozoic or Late Devonian [Aleksandrowski et al., 1999; Mazur et al., 2006]. The $D_{2 z}$ deformation in the Zábreh Unit was correlated with the pervasive vertical shortening that affected the core of the OSD, interpreted by Chopin et al. [2012a] as a ductile thinning of the exhumed rocks of the dome. These authors also proposed that the Zábřeh Unit slid 


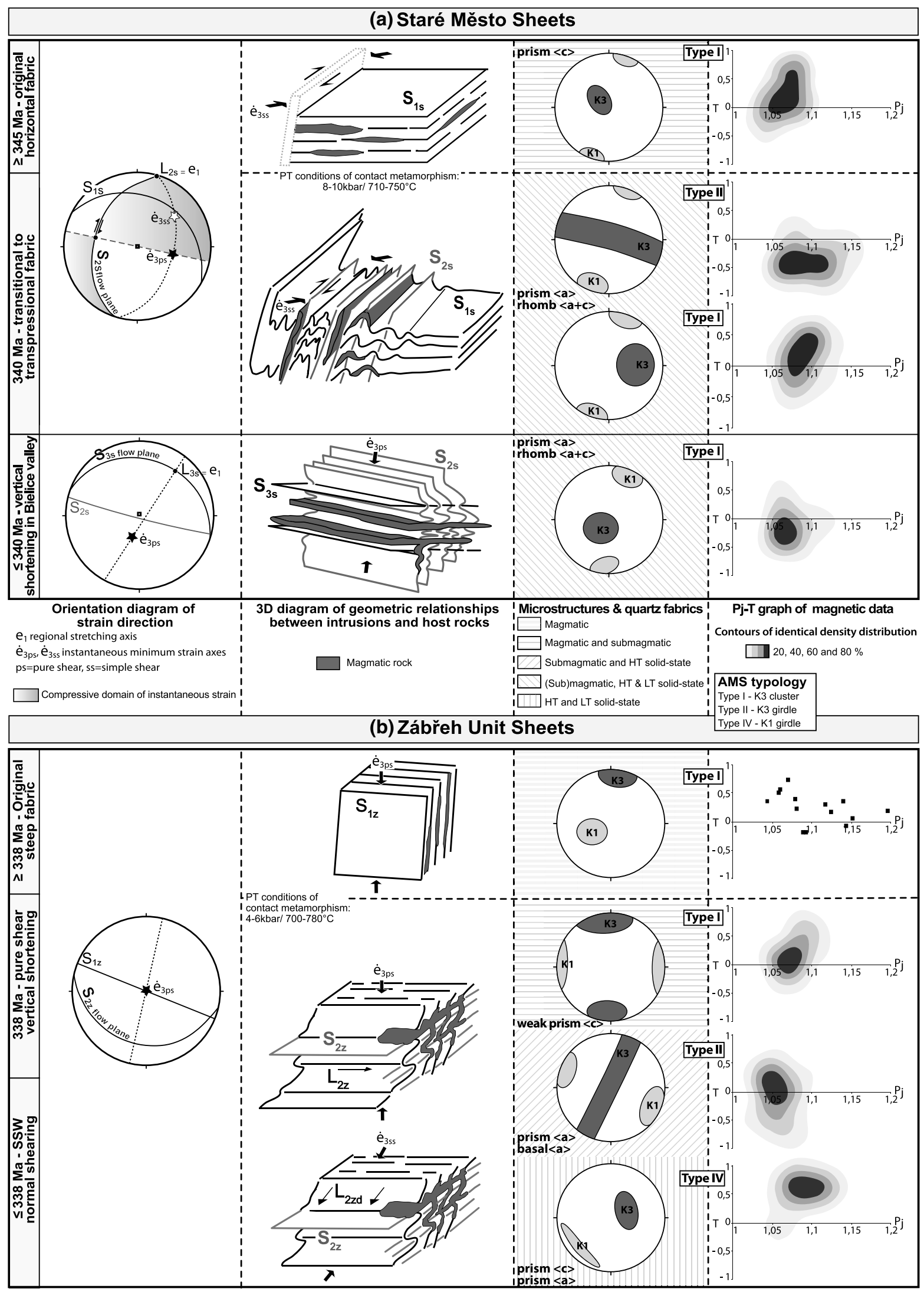

Figure 13. Summary diagram of the evolution through time for (a) the SMS and (b) the ZUS. The figures show orientation diagrams illustrating mechanisms of emplacement, 3D idealized sketches of the geometric relationships between intrusions and host rocks, and internal fabric elements of the intrusive rocks. The typology of magnetic fabrics is also indicated. 
progressively from an original apical position towards the flanks of the dome. Our data reveal that this deformation in the Zábřeh Unit is marked by a progressively decrease in degree of shortening from the OSD to the partially molten zone surrounding the ZUS, while southward, where stronger and colder rocks were not invaded by magmas, the subvertical $\mathrm{S}_{1 \mathrm{z}}$ fabric is only gently affected by $\mathrm{F}_{2 \mathrm{z}}$ recumbent folding (Figures 5b and 5c). Symmetrical recumbent folding and absence of syn- $\mathrm{D}_{2 \mathrm{z}}$ kinematic criteria in the field are in agreement with a pure shear-dominated vertical shortening. However, we argue that the formation of the down-dip lineation $\mathrm{L}_{2 z d}$ at the bottom of the Zábreh Unit and within the OSD is related to a late orogenic event: a major brittleductile detachment which is described in the western and adjacent Nové Město Unit [Mazur et al., 2005] and in the core of the dome [Chopin et al., 2012a]. In summary, $\mathrm{D}_{2 \mathrm{z}}$ could be decomposed in an upward ductile thinning propagating from the OSD to the Zábřeh Unit followed by a SSW-directed detachment in ductile-brittle conditions.

[41] It is shown here that the geodynamic evolution of the studied magmatic system is connected to the development of the OSD gneiss dome as proposed by Chopin et al. [2012a]. The present study reports that lithologies at the base of the Zábřeh Unit are identical with those of the Staré Město Unit, with a main difference in Variscan peak pressure metamorphic conditions of 4-6 kbar and 8-10 kbar, respectively. Based on this pressure difference, we suggest that the Zábřeh Unit forms an upper crustal continuity of deeper crust of the Staré Město Unit. Pre-orogenic crustal layering is represented by the $\mathrm{S}_{1 \mathrm{~s}}$ shallow-dipping Cambrian metamorphic foliation preserved in the Staré Město Unit. Our structural, AMS, and microstructural study complete the model of Chopin et al. [2012a] and show that during the early Carboniferous, the Staré Město Unit represented a stiff heterogeneity bounded to the west by the OSD orogenic root [Štipská et al., 2001]. This is along the OSD-Staré Město Unit steep interface that overpressurized magma probably percolated from a deeper magmatic chamber. The horizontal WNW-ESE shortening related to early stages of growth of the OSD dome was responsible for invasion of $\mathrm{S}_{1 \mathrm{~s}}$-parallel granitoid sills (Figure 12a). Development of steep crustal folds was associated with formation of the $S_{1 z}$ subvertical foliation in the ZUS (Figure 12a). This deformation in the Staré Město Unit produced folding of magmahosting rock shallow-dipping multilayers, leading to the formation of the $S_{2 s}$ axial planar cleavage and associated dextral transpressive shearing [Parry et al., 1997] (Figure 12b). The main volume of magma was emplaced along the $S_{2 s}$ axial plane cleavage, creating a steep magma lubricated low viscosity layer along which the OSD rocks were exhumed [Śtípská et al., 2001]. Progressive growth of the OSD permits migration of magma from the SMS towards the apex of the crustal bulge (Figure 12a). As a consequence of the upward motion of OSD lithologies, vertical shortening (or ductile thinning) of the upper horizons of the OSD and Zábřeh Unit produced horizontal dilation of the steep $S_{1 z}$ anisotropy which was filled by granitoid magma. Continuous oblique thrusting and exhumation of the OSD over the SMS is recorded by progressive solidification of magma at amphibolite and greenschist facies conditions and formation of the synmagmatic greenschist facies cleavage in the central part of the SMS (the Bielice valley). In the ZUS, $S_{2 z}$ foliation-parallel injections of sheets were syntectonic to the ductile thinning event passing to noncoaxial SSW directed detachment of the growing OSD core (Figure 12b).

\subsection{Mechanisms of Emplacement of Magmatic Sheets}

[42] Here, we will evaluate the different parameters which could control the geometries of the SMS and ZUS, such as the regional stress field, strain distribution, rheological contrasts, preexisting anisotropies, and magma overpressure. The synkinematic character of emplacement of both SMS and ZUS is well supported by (1) the concordance of the intrusive fabrics with the early Carboniferous deformation affecting the country rocks; (2) magmatic, submagmatic to subsolidus microstructural evidence; and (3) coincidence between $\sim 340$ Ma age of intrusions and onset of transpressive activity in the SMS and ductile thinning in the ZUS, respectively [Chopin et al., 2012a]. Therefore, syntectonic emplacements of magma in compressive and extensional tectonic regimes are discussed [Cosgrove, 1997; Brown and Solar, 1998; Vernon and Paterson, 2001; Žák et al., 2005; Kisters et al., 2009; Reichardt and Weinberg, 2012].

\subsubsection{Emplacement of the SMS}

[43] We have shown that (1) the SMS emplacement is syntectonic to the $\mathrm{D}_{2 \mathrm{~s}}$ dextral simple shear-dominated transpression, (2) the intrusive rocks revealing magmatic and solid-state microstructures have identical magnetic fabrics (map of Figure 7 and Figures 7a, 7b, and 7d) and, (3) the mineral and stretching lineation $\mathrm{L}_{2 \mathrm{~s}}$ in the host rocks, the magmatic lineation $\mathrm{L}_{\mathrm{m}}$, and the magnetic lineation $\mathrm{K}_{1}$ are collinear (Figure 2c and 7d). Hence, the orientation of the instantaneous extension axes in the magma did not change during subsequent solid-state reworking, implying in turn that the mineral magmatic lineation $\mathrm{L}_{\mathrm{m}}$ is close to the direction of finite extension ( $\mathrm{e}_{1}$, Figure 13a), provided that all the lineations are parallel to the stretching axis. For such a kinematic regime, the instantaneous shortening direction $\left(\dot{\mathrm{e}}_{3 \mathrm{ss}}\right)$ belongs to a plane dipping to the ESE which bears the finite extension direction $\left(\mathrm{e}_{1}\right)$ and which is in the compressive sector for simple shear making 0 to $90^{\circ}$ with the strike of the SMS. Plotting the $\mathrm{S}_{1 \mathrm{~s}}$ plane and the strain axes in an equal-area plot shows that the direction of instantaneous shortening ( $\left.\dot{\mathrm{e}}_{3 \mathrm{ss}}\right)$ is subparallel to the $\mathrm{S}_{1 \mathrm{~s}}$ foliation (Figure 13a).

[44] Important mechanistic implications can be derived for the emplacement of the $\mathrm{S}_{1 \mathrm{~s}}$-parallel magmatic sheets. Since this Cambrian crustal fragment was significantly cooled, probably to less than $450^{\circ} \mathrm{C}$ before the emplacement of the SMS [Śtipská et al., 2001], it was certainly brittle with a strong shallow-dipping mechanical anisotropy at the onset of magma intrusion [Lexa et al., 2005]. Vertical dilation is produced when such an anisotropic system is submitted to horizontal shortening at high (melt) pressure (Figure 13a; Price and Cosgrove [1990] and Cosgrove [1997]). Formation of dilatant foliation-parallel veins was successfully modeled by Barraud et al. [2001; 2004] who showed that, at the onset of shortening, melt-filled veins with high aspect ratios open along the foliation for highly anisotropic and partially molten materials. Once the magma is emplaced parallel to $\mathrm{S}_{1 \mathrm{~s}}$, the whole system becomes weaker and starts to behave as a solid rock/melt multilayer marked by high viscosity contrasts. Consequently, the critical buckle stress of the horizontal anisotropy drops and the layers buckle into 
(a) Staré Město Sheets (SMS)

poles to (001)-planes of biotite and (010)-planes of amphibole
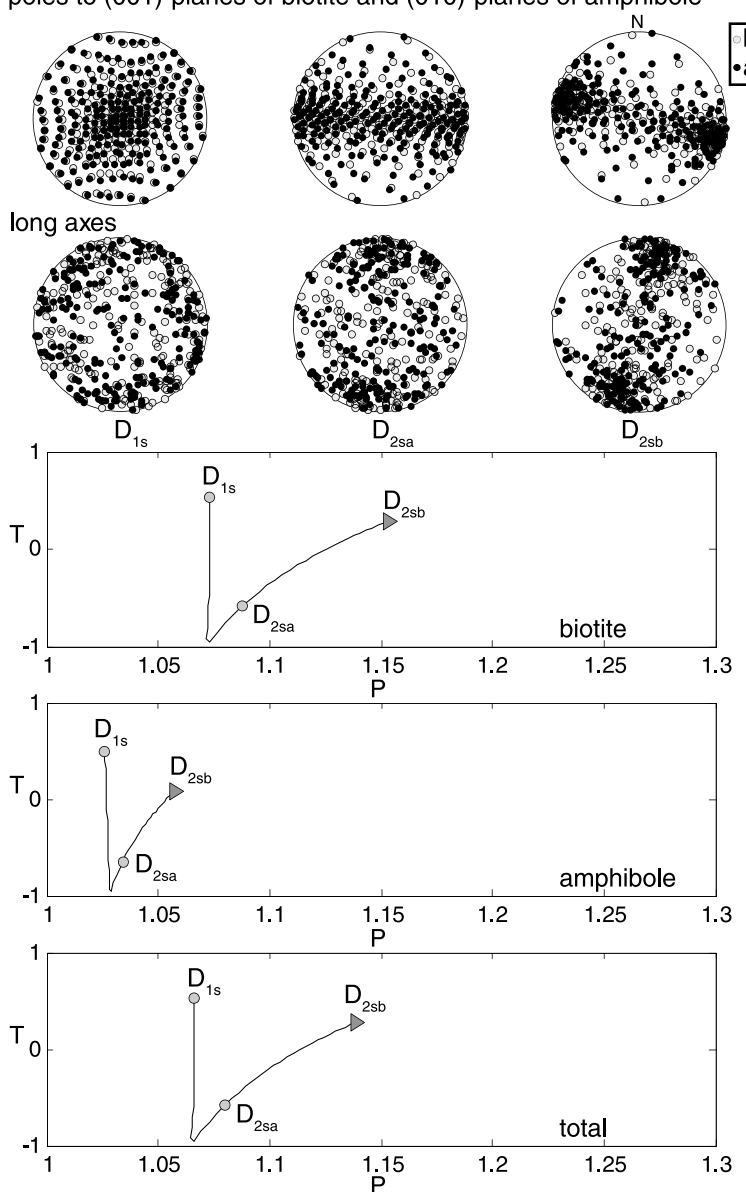

(b) Zábřeh Unit Sheets (ZUS)

poles to (001)-planes of biotite and (010)-planes of amphibole
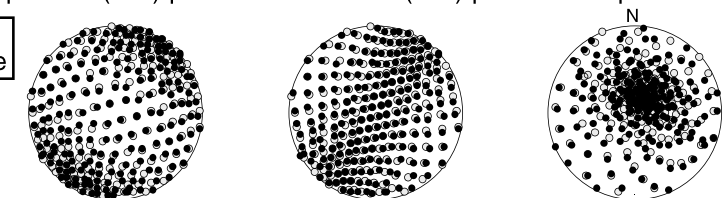

long axes
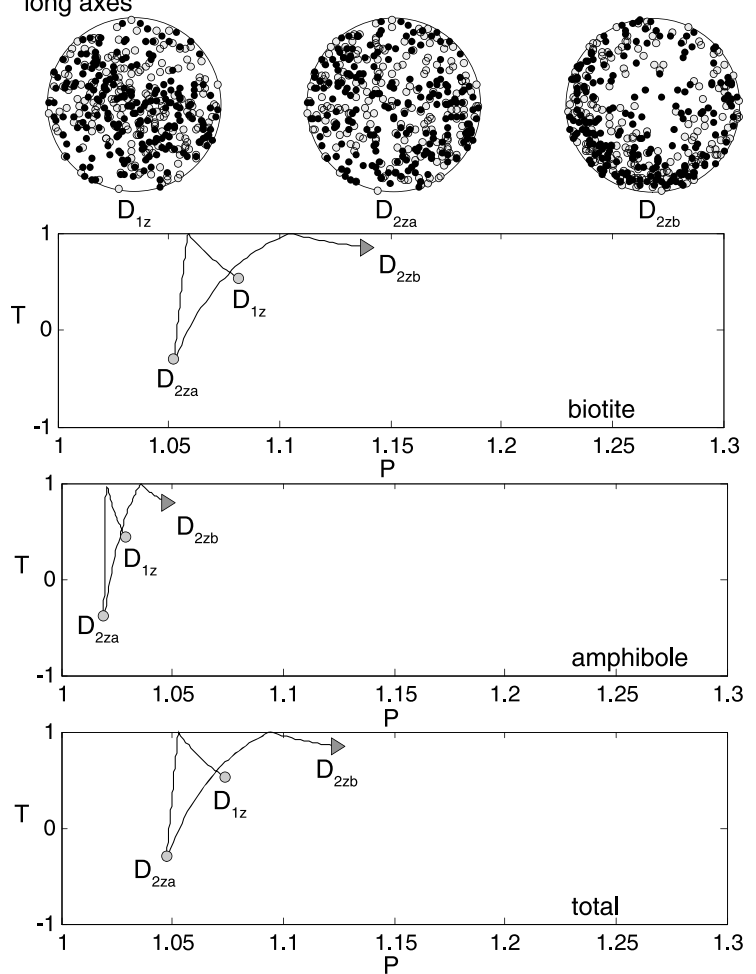

Figure 14. Results of numerical simulations of AMS fabrics during (a) horizontal flat fabric $\left(\mathrm{D}_{1 \mathrm{~s}}\right)$ overprinted by oblique transpression with dextral simple shear component $\left(\mathrm{D}_{2 \mathrm{sa}}\right.$ and $\left.\mathrm{D} 2_{\mathrm{sb}}\right)$ in the SMS and (b) subvertical intrusive fabric $\left(\mathrm{D}_{1 \mathrm{z}}\right)$ flattened by pure shear $\left(\mathrm{D}_{2 z a}\right)$ combined with horizontal simple shear $\left(\mathrm{D}_{2 \mathrm{zb}}\right)$ in the ZUS. Equal-area plots: gray circle, biotite; black circle, amphibole. See text for details.

east-verging overturned folds with subhorizontal axes (Figures 12a and 13a). Finally, the gabbros and the banded amphibolites become completely transposed into the WNW-dipping planar fabric. At this stage most of the magma is emplaced and solidifies parallel to $S_{2 s}$ as demonstrated by parallel magmatic, submagmatic, and solid-state fabrics with identical kinematics (Figure 13a). In conclusion, and as already described by Wickham [1987] and Vernon and Paterson [2001], magma emplacement parallel to $\mathrm{S}_{2 \mathrm{~s}}$ is possible because magma pressure is able to overcome the principal shortening plus the tensile strength of the rock parallel to the principal shortening.

[45] The kinematic framework in the Bielice valley is marked by a synmagmatic gently NNE-dipping cleavage development, associated with a weakly prolate magnetic fabric, and a plano-linear $\mathrm{S}_{3 \mathrm{~s}}$ with a down-dip mineral and stretching lineation $\mathrm{L}_{3 \mathrm{~s}}$ (Figures 3a, 3c, and 7e). The minimum strain axis for pure shear ( $\dot{\mathrm{e}}_{3 \mathrm{ps}}$ ) belongs to a NE-SW striking steep plane which bears $\mathrm{L}_{3 \mathrm{~s}}$ (Figure 13a). In a stereographic projection, the steep $\mathrm{S}_{2 \mathrm{~s}}$ layering belongs to the compressive sector for shortening. Since $\mathrm{D}_{3 \mathrm{~s}}$ took place at LT in greenschist facies conditions, we argue that the host rock displayed a strong anisotropic tensile strength, favorable for horizontal dilation of steep anisotropy during vertical shortening, which further enhanced invasion of magma along $\mathrm{S}_{2 \mathrm{~s}}$. Such a magma-host rock multilayer collapsed, with magma accumulation into the $F_{3 s}$ axial planes in a similar way as discussed above.

\subsubsection{Emplacement of the ZUS}

[46] The magmatic emplacement is syntectonic to $D_{2 z}$, which started and developed as a pure shear subvertical shortening. In case of oblate strain, the finite elongation occurs inside of a subhorizontal plane normal to the direction of principal shortening. In the stereographic projection (Figure 13b), the shortening direction for pure shear $\left(\dot{\mathrm{e}}_{3 \mathrm{ps}}\right)$ plots onto the $S_{1 z}$ foliation. In such kinematic frame, every subvertical plane reaches criteria for tensile failure. Buriánek et al. [2003] determined a pressure of 4-5 kbar for the ZUS emplacement. This indicates that the Zábreh Unit was located at upper-structural levels and was competent enough before magma emplacement. Therefore, magma overpressure combined with $\mathrm{S}_{1 z}$ subparallel to the vertical shortening in upper crustal conditions produced a horizontal dilation causing the intrusion of subvertical $\mathrm{S}_{1 \mathrm{z}}$-parallel magmatic sills. 
Independent upward movement of the magma was then possible because magmatic pressure at the tip of the sill exceeded the lithostatic pressure [Kisters et al., 2009]. Such a multilayer system along with the surrounding thermally weakened host rocks likely became very weak during the outgoing $\mathrm{D}_{2 \mathrm{z}}$ layer parallel shortening, resulting in subvertical shortening and folding of the $\mathrm{S}_{1 z}$ of the Zábreh Unit. Locally, minor foliation-parallel sheets emplaced along the new $\mathrm{S}_{2 z}$ cleavage (Figure 5d), possibly because the differential stress in such anatectic rocks was very small and smaller than the difference between the tensile strength in the rock parallel and normal to $\mathrm{S}_{2 \mathrm{z}}$ (according to concept of Cosgrove [1997]).

\subsection{Kinematic Interpretations of the Internal Fabrics}

[47] It has been demonstrated that the emplacement of the SMS and ZUS was controlled by the orientation of the pre-existing anisotropy, thermal state of the host rocks, and regional stress field. However, questions still remain about the relationships between magma flow and deformation of the host rocks, cooling rates during deformation, and rheological behavior of syntectonically emplaced SMS and ZUS.

[48] The northern SMS is a decoupling horizon between a stiff Cambrian fragment to the east and an exhuming, hot orogenic root to the west. There, an E-W zonation of the internal fabric accounts for this decoupling mechanism. Along the eastern margin, a subtle Type $\mathrm{I}-\mathrm{K}_{3}$ cluster fabric with shallow-dipping magnetic foliations is interpreted to result from magmatic flow along $\mathrm{S}_{1 \mathrm{~s}}$ (Figure $7 \mathrm{c}$ ). Fast cooling (preserved magmatic to submagmatic microstructures and weak quartz CPO, map of Figure 7, Figures 6a, 6b, and 9a) associated with inability of SMS magmatic sheets to transmit shear stress generated during OSD dome construction to the west allows this domain to be protected from $\mathrm{D}_{2 \mathrm{~s}}$, and to preserve fabrics that record emplacement flow of the magma during dilation of $\mathrm{S}_{1 \mathrm{~s}}$ enhanced by onset of activity of $\mathrm{D}_{2 \mathrm{~s}}$ (Figure 13a). Instead, the western margin was strongly affected by $\mathrm{D}_{2 \mathrm{~s}}$ as revealed by identical host rock fabrics and Type I magnetic fabrics (Figure 7a), generally high-strain solid-state microstructures and quartz textures consistent with dextral kinematic criteria (map of Figure 7 and Figure 9b). Between these two domains, $\mathrm{D}_{2 \mathrm{~s}}$ was moderately and heterogeneously reworking the primary shallow-dipping intrusive fabric, and produced a Type III-transitional fabric marked by $\mathrm{K}_{3}$ E-W girdle of magnetic fabrics (Figures $7 \mathrm{~b}$ and $13 \mathrm{a}$ ). To the south, in the central and southern SMS, complete mechanical coupling with the deformation in the OSD rocks produced synmagmatic to solid-state folding of $S_{1 s}$-parallel sheets (Type II-transitional fabric) and $\mathrm{S}_{2 \mathrm{~s}}$-axial-planar sills (west-dipping Type I-cluster fabric, Figures 7e and 13a).

[49] In the ZUS, a primary ascent-related fabric is rarely preserved and only revealed by a Type $\mathrm{I} \mathrm{S}_{1 z}$-parallel foliation with a subtle steep lineation (Figures $8 \mathrm{a}, 8 \mathrm{~b}$, and $13 \mathrm{~b}$ ). It is suggested that Type II-III-transitional fabrics (Figures 8d, $8 \mathrm{e}$, and $8 \mathrm{f}$ ) represent incremental superimposition of $\mathrm{D}_{2 \mathrm{z}}$ on this steep original fabric. Indeed, the girdles which are developed around an axis broadly subparallel to the magmatic lineation $\mathrm{L}_{\mathrm{m}}$, and to the fold axis of $\mathrm{F}_{2 \mathrm{z}}$ fold and mineral and intersection lineation $\mathrm{L}_{2 z}$ of the country rock reveal a change from vertical magma ascent to flow in limbs and ponding in hinges of $\mathrm{F}_{2 \mathrm{z}}$ folds (Figure 13b). Last $\mathrm{D}_{2 \mathrm{z}}$ increments produced a relatively strong anisotropic Type IV solid-state $\mathrm{S}_{2 \mathrm{z}}$-parallel fabric (Figures 8a, 8h, and 13b). The main magmatic sheet (profile 3 in Figure $8 \mathrm{a}$ ) shows an internal zonation marked by Type I $S_{2 z}$-parallel fabrics at the margins (Figure $8 \mathrm{f}$ ) and Type II girdle in the core (Figure 8e). This indicates that the strain distribution in the magma was mainly controlled by movement of the walls. The incremental evolution of $\mathrm{D}_{2 \mathrm{z}}$ strain recorded in the magmatic rocks is systematically correlated with a progressive overprint of subsolidus LT microstructures on magmatic fabrics which indicates the synkinematic cooling of the ZUS (Figure 13b). In summary, the ZUS AMS and microstructural evolution is compatible with the regional ductile thinning event as revealed by (1) original buoyancy-driven ascent of magma, (2) synmagmatic folding and ponding in low pressure areas such as hinges of $\mathrm{F}_{2 \mathrm{z}}$ folds, and (3) final crystallization and subsolidus deformation in $\mathrm{S}_{2 z}$-parallel sheets. Evidence for change in kinematics from ductile thinning to normal shear is provided by the quartz fabrics data (Figures 9c and 10), meaning that this switch is a late to postmagmatic event.

\subsection{A Model of Origin of Magnetic Fabrics}

[50] The two different evolutions of magnetic fabrics can be schematized in terms of contrasting types of fabric superimpositions. In the SMS domain, the initially shallow-dipping fabric $\left(D_{1 s}\right)$ was overprinted by an oblique transpression with dextral simple shear component $\left(\mathrm{D}_{2 \mathrm{~s}}\right)$. In the ZUS domain, the subvertical intrusive fabric $\left(\mathrm{D}_{1 \mathrm{z}}\right)$ was flattened by pure shear $\left(\mathrm{D}_{2 z \mathrm{za}}\right)$ combined with horizontal simple shear and sliding $\left(\mathrm{D}_{2 \mathrm{zb}}\right)$ along the apical part of the ascending gneiss dome. To test this hypothesis, numerical models of magnetic fabric were developed under corresponding conditions. Biotite and amphibole are considered as the main carriers of magnetic anisotropy having the following parameters $\mathrm{P}$ (anisotropy degree) and $\mathrm{T}$ (shape): biotite $\mathrm{P}=1.34, \mathrm{~T}=0.88$; and amphibole $\mathrm{P}=1.14, \mathrm{~T}=0.53 \quad$ [Borradaile and Jackson, 2004]. Biotite is almost perfectly oblate with axial ratios $5: 4: 1$ and amphibole is triaxial, $3: 2: 1$. Conformably to the bulk-rock susceptibility and modal abundances, the relative contributions to bulk magnetic susceptibility of biotite with respect to amphibole is estimated as 80/20 (given the typical values of mean susceptibility and presence of both minerals in studied rock samples). Due to the strong triaxiality of amphibole, we used the model of rigid body rotation in a viscous fluid developed by Jeffery [1922] and its numerical implementation by Ježek et al. [1994]. Given the size of biotite and amphibole crystals and temperature conditions during fabric development, we consider the model to reflect reasonably well the creation of a magnetic fabric under given conditions of tectonic deformation.

[51] The models of fabric evolution in the SMS are shown in Figure 14a. Here, the dilation created space into horizontally anisotropic amphibolites of the Staré Město Unit along which were emplaced sills bearing shallow-dipping magmatic foliation $\left(\mathrm{S}_{1 \mathrm{~s}}\right)$, as indicated in Figure 14a. This fabric is shown in stereoplots (left column) and is a starting point in AMS P-T diagrams calculated separately for biotite, amphibole, and then for total fabric. According to our model, the $\mathrm{D}_{1 \mathrm{~s}}$ fabric was created by vertical flattening with slightly more pronounced stretching in the direction $120^{\circ}$, which is the direction of the 
instantaneous elongation axis $\left(\dot{\mathrm{e}}_{1 \mathrm{ss}}\right)$ at the onset of $\mathrm{D}_{2 \mathrm{~s}}$. This configuration reflects the injection of magma into a horizontal anisotropy parallel to the horizontal shortening direction. $\mathrm{D}_{1 \mathrm{~s}}$ was further overprinted by oblique transpression with a dextral simple shear component. In the first part of the overprint $\left(\mathrm{D}_{2 \mathrm{sa}}\right)$, a girdle of poles to (001) planes of biotite and $(010)$ planes of amphibole develops associated with a strong lineation of long axes of amphibole and a zone axis of biotite (zone axis corresponding to highly girdled orientations of $\mathrm{K}_{2}$ and $\mathrm{K}_{3}$ ). This fabric shows prolate symmetry for the AMS ellipsoid $(\mathrm{T}<0)$. During continuation of the deformation process, the pure shear component of transpression $\left(\mathrm{D}_{2 \mathrm{sb}}\right)$ becomes gradually more important and leads to the development of a vertical foliation represented by pole clusters close to the periphery of the diagram $\mathrm{D}_{2 \mathrm{sb}}$ of Figure $14 \mathrm{a}$. At the same time, a strong linear fabric oriented NNESSW can be seen in the diagram of long axes. The corresponding fabric returns in the oblate region of AMS P-T graph.

[52] Modeling of the fabric evolution on the ZUS is shown in Figure $14 \mathrm{~b}$. The deformation $\mathrm{D}_{1 \mathrm{z}}$ created the vertical magmatic foliation of the ZUS emplaced in the upper part of the dome into vertically anisotropic rocks of the Zábreh Unit (see Figure 14b). This fabric shown in stereoplots (left column) exhibits a vertical foliation striking $120^{\circ}$ and bearing weak vertical lineation marked by zone axis of biotite and preferred orientation of long axes of amphibole. $\mathrm{D}_{1 \mathrm{z}}$ was flattened by pure shear $\left(\mathrm{D}_{2 z \mathrm{za}}\right)$ and subsequently by horizontal simple shear and sliding $\left(\mathrm{D}_{2 \mathrm{zb}}\right)$ along the boundary of the ascending gneissic dome. The two stages of deformation approximate the process of progressive tilting (rotation around a horizontal axis) of deforming magmatic sheets as they slide from the top to the side during the upward motion of the dome. During the first stage $\left(D_{2 z a}\right)$, the fabric becomes prolate, as seen in the AMS P-T diagram and illustrated by zonal lineation of biotite in the pole plot and by weak preferred orientation of long axes of amphibole. In the second stage $\left(\mathrm{D}_{2 \mathrm{zb}}\right)$, where simple shear produced an instantaneous shortening direction SSWplunging at $45^{\circ}$ and represents the deformation of the ZUS shifted to the side of the dome, the fabric gets more and more oblate (see P-T path) and develops a more inclined foliation and scattered lineations with weak maxima in the SSW direction.

\subsection{Significance of AMS Fabric Patterns in Transpressive and Ductile Thinning Domains}

[53] Results of modeling of the magnetic fabric evolution of the SMS (Figure 14a) indicate that the $\mathrm{D}_{1 \mathrm{~s}}$ fabric is related to the Type $I-K_{3}$ cluster distribution, the fabric $D_{2 s a}$ corresponds to Type II- $\mathrm{K}_{3}$ girdle distribution, and the fabric $\mathrm{D}_{2 \mathrm{sb}}$ matches with Type III-incomplete $\mathrm{K}_{3}$ girdle distribution (Figure 13a). Therefore, we propose that the three distinct magnetic fabrics observed along the SMS originated as a result of progressive transpressional deformation reworking originally horizontal Type $\mathrm{I}-\mathrm{K}_{3}$ cluster fabric during which the Type II-K $\mathrm{K}_{3}$ girdle and Type III-incomplete $\mathrm{K}_{3}$ girdle are a result of one deformation regime as shown in Figure 13a.

[54] Numerical simulation of the three magnetic fabrics observed in the ZUS indicates that the primary vertical intrusive fabric $\mathrm{D}_{1 \mathrm{z}}$ (Figure 14b, upper left column) corresponds to a Type $\mathrm{I}-\mathrm{K}_{3}$ cluster distribution, the fabric $\mathrm{D}_{2 \mathrm{za}}$ corresponds to Type II- $\mathrm{K}_{3}$ girdle distribution, and the fabric $\mathrm{D}_{2 \mathrm{zb}}$ matches with Type IV-K 1 girdle distribution (Figure 13b). Hence, we suggest that the AMS evolution in the ZUS is a consequence of a progressive reworking of an original steep fabric by a subvertical shortening which evolved in normal simple shear. The numerical simulation shows that the switch between ductile thinning to normal shearing is not late magmatic but more likely synmagmatic as evidenced by the modelized Type IV fabric of model $\mathrm{D}_{2 \mathrm{zb}}$ in Figure $14 \mathrm{~b}$ (corresponding to Figure 8h) using normal simple shear kinematics. Our modeling simulates well variations of AMS fabrics as proposed in sequence of diagrams in Figure 13a and 13b and which are consistent with kinematic and mechanistic models of magma emplacement.

\section{Conclusions}

[55] The data reported in this study show that emplacement of the SMS and ZUS was controlled by the orientation of inherited mechanical anisotropy. The microstructures of the magmatic rocks suggest that formation of the penetrative fabrics began during crystallization of the magma and continued during cooling at upper crustal levels. The AMS and quartz fabrics are consistent with a simple shear-dominated transpression in the SMS and a ductile thinning evolving into a detachment in the ZUS. In the absence of widely developed extension lineations and kinematic criteria in the Zábřeh Unit, the quartz CPO pattern in the ZUS represents the best available evidence for the SSW-directed normal shear zone on the southern flank of the OSD. The AMS preserved composite fabrics that record emplacement flow of magma, overprinted by orthogonal deformation driven by anisotropic tectonic stresses, pinning the magnetic lineation orientation to the intersection of multiple foliations. The AMS modelling confirmed the prominence of orthogonal deformation superimpositions on intrusive fabrics to create complex fabric patterns in syntectonic granitoids.

[56] Whereas most of the previous studies have emphasized the role of the orientation of preexisting anisotropies compared to the active regional stress field for magma emplacement, this study also highlights that a complex flow of magma is linked to the different vertical position of these anisotropies with respect to the growth dynamics of the orogenic core. Detailed microstructural and AMS studies associated with AMS modeling provide key insights to unravel subtle magmatic to solid-state flow mechanisms during ascent, emplacement and crystallization of syntectonic granitoids in orogens.

[57] Acknowledgments. Financial support of the French National Grant Agency (06-1148784 to K. Schulmann) is acknowledged. Activities of the Center for Lithospheric Research are co-financed by the Czech Ministry of Education, Youth and Sports (LK11202). The grant MSM0021620855 of the Ministry of Education of the Czech Republic and internal research funds of CNRS UMR 7516 are acknowledged for salary and financial support of $O$. Lexa. The Czech Geological Survey is acknowledged for salary support of J. Lehmann. We are grateful to M. Jati for help with preparation of AMS samples. We thank A. Bouzhegaia for help with drawing figures and K. Verner and L. Vondrovic for helpful discussions. J. Honnorez, E.G. Charlesworth, and K. Saalmann are warmly acknowledged for informal reviews. We thank $\mathrm{O}$. Bolle and two anonymous reviewers for their helpful reviews, and R. Weinberg and J.-L. Bouchez for thorough and judicious reviews of an earlier version of the manuscript. 


\section{LEHMANN ET AL.: SYNTECTONIC GRANITOID EMPLACED IN OROGEN}

\section{References}

Aleksandrowski, P., R. Kryza, S. Mazur, C. Pin, and J. A. Zalasiewicz (1999), The Polish Sudetes: Caledonian or Variscan?, Trans of the Royal Society of Edinburgh, Earth Sci, 90, 127-146.

Aleksandrowski, P., R. Kryza, S. Mazur, and J. Żaba (1997), Kinematic data on major Variscan strike-slip faults and shear zones in the Polish Sudetes, northeast Bohemian Massif, Geol. Mag., 134(5), 727-739.

Baratoux, L., K. Schulmann, S. Ulrich, and O. Lexa (2005), Contrasting microstructures and deformation mechanisms in metagabbro mylonites contemporaneously deformed under different temperatures $\left(\mathrm{c} .650^{\circ} \mathrm{C}\right.$ and c. $750^{\circ} \mathrm{C}$ ), Deformation Mechanisms, Rheology and Tectonics: from Minerals to Lithosphere, Geol. Soc. Spec. Publ., 243, 97-125.

Barraud, J., V. Gardien, P. Allemand, and P. Grandjean (2001), Analogue modeling of melt segregation and migration during deformation, Phys. Chem. Earth (A), 26(4-5), 317-323.

Barraud, J., V. Gardien, P. Allemand, and P. Grandjean (2004), Analogue models of melt-flow networks in folding migmatites, J. Struct. Geol., 26, 307-324

Benn, K. (1994), Overprinting of magnetic fabrics in granites by small strains: numerical modelling, Tectonophysics, 233(3-4), 153-162.

Benn, K. (2009), Anisotropy of magnetic susceptibility fabrics in syntectonic plutons as tectonic strain markers: The example of the Canso pluton, Meguma Terrane, Nova Scotia, Earth and Environ Sci Trans of the Royal Society of Edinburgh, 100(Special Issue 1-2), 147-158, doi:10.1017/S1755691009016028.

Borradaile, G. J., and B. Henry (1997), Tectonic applications of magnetic susceptibility and its anisotropy, Earth Sci. Rev., 42(1-2), 49-93.

Borradaile, G. J., and M. Jackson (2004), Anisotropy of magnetic susceptibility (AMS): Magnetic petrofabrics of deformed rocks, Geol. Soc. Spec. Publ., 238, 299-360.

Bouchez, J.-L. (1997), Granite is never isotropic: An introduction to AMS studies of granitic rocks, in Granite: from segregation of melt to emplacement fabrics, edited by J.-L. Bouchez, D. H. W. Hutton, and W. E. Stephens, pp. 95-112, Kluwer Academic Publishers, Dordrecht, Netherlands.

Bouchez, J.-L. (2000), Magnetic susceptibility anisotropy and fabrics in granites, Comptes Rendus de l'Academie des Sciences Series IIa Fascicule a-Sciences De La Terre Et Des Planetes, 330(1), 1-14.

Brown, M., and G. S. Solar (1998), Granite ascent and emplacement during contractional deformation in convergent orogens, J. Struct. Geol., 20(9-10), 1365-1393.

Buriánek, D., M. Německova, and P. Hanžl (2003), Petrology and geochemistry of plutonic rocks from the Policka and Zabreh crystalline units (NE Bohemian Massif), Bull. Geosci., 78(1), 9-22.

Chadima, M., and V. Jelínek (2008), Anisotropy data browser for Windows, software, edited by AGICO Inc.

Chopin, F., et al. (2012a), Crustal influx, indentation, ductile thinning and gravity redistribution in a continental wedge: Building a Moldanubian mantled gneiss dome with underthrust Saxothuringian material (European Variscan belt), Tectonics, 31(1), TC1013, doi:10.1029/2011tc002951.

Chopin, F., K. Schulmann, P. Stípská, J.-E. Martelat, P. Pitra, O. Lexa and B. Pétri (2012b), Microstructural and metamorphic evolution of a high-pressure granitic orthogneiss during continental subduction (Orlica-Śnieżnik dome, Bohemian Massif), J. Metamorph. Geol., 30(4), 347-376, doi:10.1111/j.1525-1314.2011.00970.x.

Cosgrove, J. W. (1997), The influence of mechanical anisotropy on the behaviour of the lower crust, Tectonophysics, 280(1-2), 1-14.

Cymerman, Z. (1997), Structure, kinematics and evolution of the Orlica-Śnieżnik Dome, Sudetes, Prace Panstwowego Instytutu Geologicznego, 156, 1-120.

Davidson, C., L. S. Hollister, and S. M. Schmid (1992), Role of melt in the formation of a deep-crustal compressive shear zone: The Maclaren Glacier metamorphic belt, south central Alaska, Tectonics, 11(2), 348-359, doi:10.1029/91TC02907.

Davidson, C., S. M. Schmid, and L. S. Hollister (1994), Role of melt during deformation in the deep crust, Terra Nova, 6(2), 133-142.

Edel, J.-B., K. Schulmann, and F. V. Holub (2003), Anticlockwise and clockwise rotations of the Eastern Variscides accommodated by dextral lithospheric wrenching: Palaeomagnetic and structural evidence, J. Geol. Soc. Lond., 160, 209-218.

Franke, W., and A. Zelazniewicz (2000), The eastern termination of the Variscides: Terrane correlation and kinematic evolution, in Orogenic processes: Quantification and Modelling in the Variscan belt, edited by W. Franke, V. Haak, O. Oncken, and D. Tanner, Geol. Soc. Spec. Publ., $179,63-86$.

Galland, O., P. R. Cobbold, J. de Bremond d'Ars, and E. Hallot (2007), Rise and emplacement of magma during horizontal shortening of the brittle crust: Insights from experimental modeling, J. Geophys. Res. B Solid Earth, 112(6), 21, doi:10.1029/2006JB004604
Gapais, D. (1989), Shear structures within deformed granites: Mechanical and thermal indicators, Geology, 17, 1144-1147.

Hollister, L. S., and M. L. Crawford (1986), Melt-enhanced deformation: A major tectonic process, Geology, 14, 558-561.

Hutton, D. H. W. (1988), Igneous emplacement in a shear zone termination: The biotite granite at Strontian, Scotland, Geol. Soc. Am. Bull., 100, 1392-1399.

Ingram, G. M., and D. H. W. Hutton (1994), The Great Tonalite Sill: Emplacement into a contractional shear zone and implications for Late Cretaceous to Early Eocene tectonics in southeastern Alaska and British Columbia, Geol. Soc. Am. Bull., 106, 715-728.

Jeffery, G. B. (1922), The motion of ellipsoidal particles immersed in a viscous fluid, Proc. R. Soc. Lond., 102(715), 161-179.

Jelínek, V. (1977), The Statistical Theory of Measuring Anisotropy of Magnetic Susceptibility of Rocks and its Application, Geofyzika Brno, Brno, 87 pp.

Jelínek, V. (1978), Statistical processing of anisotropy of magnetic susceptibility measured on groups of specimens, Studia geophysica et geodetica, $22,50-62$.

Ježek, J., and F. Hrouda (2002), A technique for numerical modeling of magnetic anisotropy to strain relationship, Phys. Chem. Earth. 27(25-31), 1247-1252.

Ježek, J., R. Melka, K. Schulmann, and Z. Venera (1994), The behaviour of rigid triaxial ellipsoidal particles in viscous flows; modeling of fabric evolution in a multiparticle system, Tectonophysics, 229 (3-4), 165-180.

Ježek, J., K. Schulmann, and K. Segeth (1996), Fabric evolution of rigid inclusions during mixed coaxial and simple shear flows, Tectonophysics 257(2-4), 203-221.

Kisters, A. F. M., R. A. Ward, C. J. Anthonissen, and M. E. Vietze (2009), Melt segregation and far-field melt transfer in the mid-crust, Geological Society, London, 166(5), 905-918.

Kratinová, Z., K. Schulmann, J. B. Edel, J. Ježek, and U. Schaltegger (2007), Model of successive granite sheet emplacement in transtensiona setting: Integrated microstructural and anisotropy of magnetic susceptibility study, Tectonics, 26(6), 26.

Kröner, A., P. Štípská, K. Schulmann, and P. Jaeckel (2000), Chronological constraints on the pre-Variscan evolution of the northeastern margin of the Bohemian Massif, Czech Republic, in Orogenic Processes; Quantification and Modelling in the Variscan Belt, edited by W. Franke, V. Haak O. Oncken, and D. Tanner, Geol. Soc. Spec. Publ., 179, 175-197, Geological Society, London

Kruhl, J. H. (1996), Prism- and basal-plane parallel subgrain boundaries in quartz: A microstructural geothermobarometer, J. Metamorph. Geol. 14(5), 581-589.

Lange, U., M. Bröcker, R. Armstrong, A. Żelaźniewicz, E. Trapp, and K. Mezger (2005), The orthogneisses of the Orlica-Śnieżnik complex (West Sudetes, Poland): Geochemical characteristics, the importance of pre-Variscan migmatization and constraints on the cooling history, J. Geol. Soc. Lond., 162, 973-984.

Lattard, D., R., Engelmann, A. Kontny, and U. Sauerzapf (2006), Curie temperatures of synthetic titanomagnetites in the Fe-Ti-O system: Effects of composition, crystal chemistry, and thermomagnetic methods, J. Geophys. Res. B Solid Earth, 111(12), 18.

Lexa, O., P. Štípská, K. Schulmann, L. Baratoux, and A. Kröner (2005), Contrasting textural record of two distinct metamorphic events of similar P-T conditions and different durations, J. Metamorph. Geol., 23(8), 649-666.

Lister, G. S., and B. E. Hobbs (1980), The simulation of fabric development during plastic deformation and its application to quartzite: The influence of deformation history, J. Struct. Geol., 2(3), 355-370.

Maluski, H., P. Rajlich, and J. Soucek (1995), Pre-Variscan, Variscan and early Alpine thermo-tectonic history of the north-eastern Bohemian Massif; an ${ }^{40} \mathrm{Ar} /{ }^{39} \mathrm{Ar}$ study, Geol. Rundsch., 84(2), 345-358.

Mazur, S., P. Aleksandrowski, and J. Szczepański (2005), The presumed Teplá-Barrandian/Moldanubian terrane boundary in the Orlica Mountains (Sudetes, Bohemian Massif): Structural and petrological characteristics, Lithos, 82(1-2 SPEC. ISS.), 85-112.

Mazur, S., W. J. Dunlap, K. Turniak, and T. Oberc-Dziedzic (2006), Age constraints for the thermal evolution and erosional history of the central European Variscan belt: New data from the sediments and basement of the Carboniferous foreland basin in western Poland, J. Geol. Soc. Lond., 163(6), 1011-1024, doi:10.1144/0016-76492004-170.

Mazur, S., J. Szczepański, K. Turniak, and N. J. McNaughton (2012), Location of the Rheic suture in the eastern Bohemian Massif: Evidence from detrital zircon data, Terra Nova, 24(3), 199-206, doi:10.1111/ j.1365-3121.2011.01053.

Parry, M., P. Štípská, K. Schulmann, F. Hrouda, J. Ježek, and A. Kröner (1997), Tonalite sill emplacement at an oblique plate boundary: northeastern margin of the Bohemian Massif, Tectonophysics, 280(1-2), 61-81.

Passchier, C. W., and R. A. J. Trouw (2005), Microtectonics, SpringerVerlag, Berlin Heidelberg New York, 366 pp. 


\section{LEHMANN ET AL.: SYNTECTONIC GRANITOID EMPLACED IN OROGEN}

Paterson, S. R., T. K. Fowler, K. L. Schmidt, A. S. Yoshinobu, E. S. Yuan, and R. B. Miller (1998), Interpreting magmatic fabric patterns in plutons, Lithos, 44(1-2), 53-82.

Paterson, S. R., R. H. Vernon, and O. T. Tobisch (1989), A review of criteria for the identification of magmatic and tectonic foliations in granitoids, J. Struct. Geol., 11(3), 349-363.

Price, M. J., and J. W. Cosgrove (1990), Analysis of Geological Structures, Cambridge University Press, Cambridge, $502 \mathrm{pp}$.

Reichardt, H., and R. F. Weinberg (2012), The dike swarm of the Karakoram shear zone, Ladakh, NW India: Linking granite source to batholith, Geol. Soc. Am. Bull., 124(1/2), 89-103, doi:10.1130/B30394.1.

Schmid, S. M., and M. Casey (1986), Complete fabric analysis of some commonly observed quartz c-axis patterns, in Mineral and Rock Deformation: Laboratory Studies; the Paterson Volume, Geophysical Monograph, 36, edited by B. E. Hobbs and H. C. Heard, 263-286.

Schneider, D. A., S. J. Zahniser, J. M. Glascock, S. M. Gordon, and M. Manecki (2006), Thermochronology of the West Sudetes (Bohemian Massif): Rapid and repeated eduction in the Eastern Variscides, Poland and Czech Republic, Am J Sci, 306(10), 846-873, doi:10.2475/ 10.2006.03.

Schulmann, K., and J. Ježek (2012), Some remarks on fabric overprints and constrictional AMS fabrics in igneous rocks, Int J Earth Sci, 101(3), 705-714, doi:10.1007/s00531-011-0681-Z.

Sibson, R. H. (2003), Brittle-failure controls on maximum sustainable overpressure in different tectonic regimes, Am. Assoc. Pet. Geol. Bull., 87(6), 901-908.

Skrzypek, E., K. Schulmann, P. Štípská, F. Chopin, J. Lehmann, O. Lexa and J. Haloda (2011a), Tectono-metamorphic history recorded in garnet porphyroblasts: Insights from thermodynamic modelling and electron backscatter diffraction analysis of inclusion trails, J. Metamorph. Geol., 29(4), 473-496, doi:10.1111/j.1525-1314.2010.00925.x.

Skrzypek, E., A.-S. Tabaud, J.-B. Edel, K. Schulmann, A. Cocherie, C. Guerrot, and P. Rossi, (2011b), The significance of Late Devonian ophiolites in the Variscan orogen: A record from the Vosges Klippen Belt, International Journal of Earth Sciences, 101(4), 951-972.

Stipp, M., H. Stunitz, R. Heilbronner, and S. M. Schmid (2002), The eastern Tonale fault zone: a 'natural laboratory' for crystal plastic deformation of quartz over a temperature range from 250 to 700 degrees ${ }^{\circ} \mathrm{C}$, J. Struct. Geol., 24(12), 1861-1884.

Štípská, P., F. Chopin, E. Skrzypek, K. Schulmann, P. Pitra, O. Lexa J. E. Martelat, C. Bollinger, and E. Žáčková (2012), The juxtaposition of eclogite and mid-crustal rocks in the Orlica-Śnieżnik Dome, Bohemian
Massif, J. Metamorph. Geol., 30(2), 213-234, doi:10.1111/j.15251314.2011.00964.x.

Štípská, P., K. Schulmann, and A. Kröner (2004), Vertical extrusion and middle crustal spreading of omphacite granulite: A model of synconvergent exhumation (Bohemian Massif, Czech Republic), J. Metamorph Geol., 22(3), 179-198, doi:10.1111/j.1525-1314.2004.00508.x.

Štípská, P., K. Schulmann, A. B. Thompson, J. Ježek, and A. Kröner (2001), Thermo-mechanical role of a Cambro-Ordovician paleorift during the Variscan collision: The NE margin of the Bohemian Massif, Tectonophysics, 332(1-2), 239-253.

Tribe, I. R., and R. S. D'Lemos (1996), Significance of a hiatus in down-temperature fabric development within syntectonic quartz diorite complexes, Channel Islands, UK, J. Geol. Soc. Lond., 153(1), 127-138.

van Breemen, O., M. Aftalion, D. R. Bowes, A. Dudek, Z. Mísař, P. Povondra, and S. Vrána (1982), Geochronological studies of the Bohemian Massif, Czechoslovakia, and their significance in the evolution of Central Europe, Trans of the Royal Society of Edinburgh, Earth Sci, 73, 89-108.

Verner, K., D. Buriánek, S. Vrána, L. Vondrovic, J. Pertoldová, P. Hanžl, and R. Nahodilová (2009), Tectonometamorphic features of geological units along the northern periphery of the Moldanubian Zone (Bohemian Massif), J. Geosci., 54, 87-100, doi:10.3190/jgeosci.046.

Vernon, R. H., and S. R. Paterson (2001), Axial-surface leucosomes in anatectic migmatites, Tectonophysics, 335(1-2), 183-192.

Watanabe, K., and H. Takahashi (1994), Theoretical analysis and optimum design of hot dry rock geothermal energy extraction, in Restructuring the Geothermal Industry., edited by L. Nielson Dennis, pp. 483-489, GRC - Geothermal Resources Council, Salt Lake City.

Weinberg, R. F., and G. Mark (2008), Magma migration, folding, and disaggregation of migmatites in the Karakoram Shear Zone, Ladakh, NW India, Bull. Geol. Soc. Am., 120(7-8), 994-1009, doi:10.1130/ b26227.1.

Weinberg, R. F., and M. P. Searle (1998), The Pangong Injection Complex, Indian Karakoram: A case of pervasive granite flow through hot viscous crust, J. Geol. Soc. Lond., 155, 883-891.

Wickham, S. M. (1987), The segregation and emplacement of granitic magmas, J. Geol. Soc. Lond., 144, 281-297.

Žák, J., K. Schulmann, and F. Hrouda (2005), Multiple magmatic fabrics in the Sazava pluton (Bohemian Massif, Czech Republic): A result of superposition of wrench-dominated regional transpression on final emplacement, J. Struct. Geol., 27(5), 805-822. 